\title{
Oligodendrocyte development and the onset of myelination in the human fetal brain
}

\author{
Igor Jakovcevski' , Radmila Filipovic ${ }^{1,2}$, Zhicheng Mo ${ }^{1,3}$, Sonja Rakic ${ }^{1,4}$ and Nada Zecevic ${ }^{\text {* }}$ \\ Department of Neuroscience, University of Connecticut Health Center, Farmington, CT, USA \\ 2 Department of Physiology and Neurobiology, University of Connecticut, Storrs, CT, USA \\ ${ }^{3}$ Department of Pathology, Conemaugh Memorial Medical Center, Johnstown, PA, USA \\ ${ }^{4}$ Department of Cell and Developmental Biology, University College London, UK
}

\section{Edited by:}

Kathleen S. Rockland, RIKEN Brain

Science Institute, Japan

Reviewed by:

Javier DeFelipe, Cajal Institute (CSIC), Spain

Natasa Jovanov-Milosevic, University of Zagred, Croatia

\section{${ }^{*}$ Correspondence:}

Nada Zecevic, Department of

Neuroscience, University of

Connecticut Health Center, 263

Farmington Ave, Farmington, CT

06030-3401, USA

e-mail:nzecevic@neuron.uchc.edu
Oligodendrocytes are cells that myelinate axons, providing saltatory conduction of action potentials and proper function of the central nervous system. Myelination begins prenatally in the human, and the sequence of oligodendrocyte development and the onset of myelination are not thoroughly investigated. This knowledge is important to better understand human diseases, such as periventricular leukomalacia, one of the leading causes of motor deficit in premature babies, and demyelinating disorders such as multiple sclerosis (MS). In this review we discuss the spatial and temporal progression of oligodendrocyte lineage characterized by the expression of specific markers and transcription factors in the human fetal brain from the early embryonic period (5 gestational weeks, gw) until midgestation ( $24 \mathrm{gw}$ ). Our in vitro evidence indicated that a subpopulation of human oligodendrocytes may have dorsal origin, from cortical radial glia cells, in addition to their ventral telencephalic origin. Furthermore, we demonstrated that the regulation of myelination in the human fetal brain includes positive and negative regulators. Chemokines, such as CXCL1, abundant in proliferative zones during brain development and in regions of remyelination in adult, are discussed in the view of their potential roles in stimulating oligodendrocyte development. Other signals are inhibitory and may include, but are not limited to, polysialic acid modification of the neural cell adhesion molecule on axons. Overall, important differences in temporal and spatial distribution and regulatory signals for oligodendrocyte differentiation exist between human and rodent brains. Those differences may underlie the unique susceptibility of humans to demyelinating diseases, such as MS.

\section{Keywords: human brain development, immunohistochemistry, myelination, oligodendrocyte progenitor cells, organotypic} slice cultures, chemokines, PSA-NCAM, transcription factors

\section{INTRODUCTION}

Oligodendrocytes are glia cells that produce myelin, the lipidenriched axon-ensheathing membrane, which is essential for saltatory conduction of action potentials in the central nervous system (CNS). They were first discovered by Robertson (1899), but named and classified by Rio Hortega (1921). The origin and differentiation of oligodendrocytes have been extensively studied in animal models, and are especially well documented in rodents, thanks to advances in various molecular biology techniques that have provided the means of genetic mapping of cell lineages in the developing mouse brain (He et al., 2001; Kessaris et al., 2006; Marshall and Goldman, 2002; Rivers et al., 2008; Tekki-Kessaris et al., 2001). Along the neural tube oligodendrocytes are produced ventrally under the influence of the morphogen Sonic Hedgehog (Shh), and migrate at the progenitor stage to dorsal regions (as reviewed in Miller, 1996; Richardson et al., 2000; Spassky et al., 2000). It has been shown, however, that after the initial wave of ventrally derived oligodendrocytes, they are completely replaced by a dorsally derived population (Kessaris et al., 2006; Vallstedt et al., 2005). Progression of cells of oligodendrocyte lineage through various stages of differentiation has been described in depth in rodents using primary oligodendrocyte cell cultures (e.g. Miller, 1996; Pfeiffer et al., 1993; Raff, 1989; Reynolds and Hardy, 1997).
Furthermore, extensive studies have shown transcription factors essential for oligodendrocyte specification as well as growth factors that influence oligodendrocyte proliferation and differentiation (Lu et al., 2000, 2002; Orentas and Miller, 1996; Takebayashi et al., 2000). In the ventral diencephalon and telencephalon, Shh influences the expression of oligodendrocyte lineage genes, Olig1 and Olig2, which are basic helix-loop-helix (bHLH) transcription factors (Lu et al., 2000; Pringle et al., 1996; Takebayashi et al., 2000; Tekki-Kessaris et al., 2001; Zhou et al., 2000). The question, however, remains to which extent could observations obtained on these animal models relate to human brain development.

In the recent years our laboratory has published several studies based on immunohistochemical analysis of the human fetal brain describing early oligodendrocyte specification (Filipovic et al., 2003; Jakovcevski and Zecevic, 2005a,b; Rakic and Zecevic, 2003a) and the onset of myelination (Jakovcevski et al., 2007). We have also pioneered the use of organotypic slice cultures, as well as primary cell cultures from human fetal brains, in addressing questions of the capacity of radial glia cells to generate oligodendrocytes (Mo and Zecevic, 2009), the interplay of other cell types and oligodendrocyte progenitor cells during brain development (Filipovic and Zecevic, 2005, 2008), and axon-oligodendrocyte interactions preceding myelination (Jakovcevski et al., 2007). Here we will summarize 
results of those studies, compare them with other work published on developing human brain and put it all in the perspective of knowledge obtained from studies on animal models.

\section{METHODOLOGICAL REMARKS}

Several issues, ethical and methodological, need to be addressed regarding human fetal brain tissue. All of the tissue used in our studies was obtained after legal abortions performed either at the Obstetrics and Gynecology Clinic, University of Belgrade (Serbia), or from the Brain Bank, Albert Einstein College of Medicine (Bronx, NY). The Institutional Ethics Committees of these institutions and the University of Connecticut approved the tissue collection, and informed consent was obtained from the parents. The handling of tissue was performed in accordance with all regulations set forth by the Institutional Ethics Committees and the Helsinki Convention. No evidence of disease or developmental abnormalities was discovered after ultrasonic and neuropathological examination of fetal brains. The ages of the embryos and fetuses were estimated on the basis of weeks after ovulation, crown-rump length (Olivier and Pineau, 1962), and anatomical landmarks (O'Rahilly et al., 1987).

Tissue was fixed by submersion into $4 \%$ formaldehyde in $0.1 \mathrm{M}$ phosphate buffer, typically within $15 \mathrm{~min}$, but never longer than $2 \mathrm{~h}$ post-mortem, which is among the shortest reported in the literature. Fixation times varied depending on the size of the tissue block, but were never shorter than overnight. Fixation was always done at $4{ }^{\circ} \mathrm{C}$, followed by cryoprotection in $30 \%$ sucrose solution in the same buffer, and freezing of tissue in isopentane cooled to $-70^{\circ} \mathrm{C}$. Despite very careful attempts made to standardize the conditions for each case, considerable differences in immunoreactivity to certain antibodies could be detected. Each immunostaining has to be evaluated by an experienced observer and antibody reactivity has to be assessed on case-to-case basis. Only cells that displayed typical morphology and distribution of the antigen as predicted (i.e. transcription factors are nuclear, receptors are on the cell membrane) were used in evaluation. Another source of difficulties in working with human tissue is that optimal antibody dilutions are difficult to determine, since each individual sample may vary in reactivity to some antibodies. However, for most of the antibodies used in our studies we have been able to get fairly reproducible staining intensities. The antibodies and tissue samples that resulted in great variability in staining intensity and/or staining pattern were thus excluded from our analyses.

To be able to do experimental manipulation with human brain tissue, we have developed primary cell cultures and slice cultures from human fetal forebrains (Figure 1). These cultures are different from cultures taken from experimental animals in several respects. Firstly, human fetal cells are harvested from only one brain specimen at the time, unlike in animals where one whole, or even several litters can be pooled in order to obtain cells in optimal numbers. Additionally, the factors that greatly increase case-to-case variability of these cultures include genetic differences (humans are rarely "inbred"), age differences (age of the fetus is never completely precise within 1-2 weeks), and different conditions of tissue before cultures are made. In order to standardize to the maximum tissue quality as the only addressable problem among those mentioned above, we have devised a protocol to keep tissue in oxygenated buffered saline solution supplemented with glucose and glutamine on ice during transport. Transportation time is typically $<2 \mathrm{~h}$. In this way after preparation of cultures usually less then $10 \%$ of cells are dead as assessed by trypan-blue staining (Mo et al., 2007).

In addition to long-term cell cultures (min. and max. time, $12 \mathrm{~h}$ to 5 days), which we used to study radial glia cells (Mo and Zecevic, 2008, 2009; Mo et al., 2007), and oligodendrocytes (Filipovic and Zecevic, 2005, 2008), we also established acute cell cultures (Howard et al., 2006; Jakovcevski and Zecevic, 2005b). Acute cultures are dissociated cells from well-defined brain regions, maintained for 4-6 h

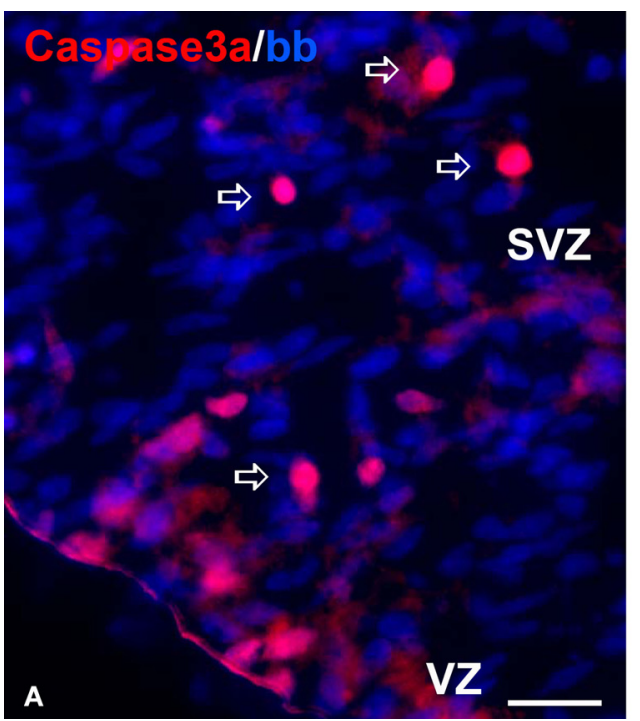

10

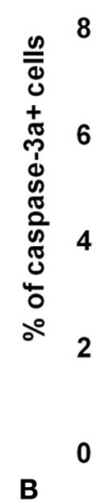

FIGURE 1 | Cell death in chronic slice cultures. (A) The representative image of activated caspase-3 staining (red, arrows) on the ventricular/subventricular zone (VZ/SVZ) of the slice culture from a 19-week-old human fetus after 5 days in vitro. Nuclei are counterstained with bisbenzamide (blue). Scale bar: $20 \mu \mathrm{m}$.
(B) Proportion of caspase-3a+ cells in all bisbenzamide-labeled nuclei in the VZ/ SVZ and intermediate zone/cortical plate (IZ/CP) of 19-week-old human fetus. Note the higher percentage of apoptotic cells in the VZ/SVZ, similar to results obtained by TUNEL staining on frozen sections (Rakic and Zecevic, 2000). 
before fixation and immunostaining. They were used to estimate the proportions of marker-defined cell populations among all cells in the region (Figures 6C,D).

In order to manipulate experimental conditions, but still preserve cell-to-cell interactions and extracellular matrix composition present in vivo, we have established organotypic slice culture from the human fetal forebrains. Brain slices were kept for 3-5 days in vitro. Under culture conditions cells in slices retained viability after 5 days with very little cell death as shown by activated caspase-3 staining (Figure 1). In addition, both cell proliferation and normal cellular composition, judged by the staining patterns with the cell-type specific antibodies, closely resembles in vivo sections from the same age. However, there are a few exceptions to this, most notably the oligodendrocyte maturation seems to be accelerated in slices, as discussed below (Jakovcevski and Zecevic, 2005a; Jakovcevski et al., 2007).

\section{SEOUENTIAL EXPRESSION OF IMMUNOHISTOCHEMICAL MARKERS DURING PROGRESSION OF OLIGODENDROCYTE LINEAGE IN HUMANS}

Oligodendrocyte lineage has been described in detail in rodents by expression of specific proteins used as immunomarkers of various stages in oligodendrocyte development (e.g., Pfeiffer et al., 1993). Oligodendrocytes are also the cell population in the central nervous system with the most significant turnover, and as such, all stages of precursor cells exist in the CNS throughout adult life (Dawson et al.,
2003). Oligodendrocyte development in humans begins during the second trimester of gestation and progresses towards birth, and further into adulthood (Back et al., 2001; Jakovcevski and Zecevic, 2005a; Rakic and Zecevic, 2003a; Rivkin et al., 1995; Yakovlev and Lecourse, 1967). We focused recently on elucidating progression of oligodendrocyte lineage in humans in the first half of gestation (Figure 2).

Early oligodendrocyte progenitor cells are characterized by their expression of platelet derived growth factor receptor alpha (PDGFR $\alpha$ ) and NG2 proteoglycans (Pringle and Richardson, 1993; Pringle et al., 1992; Stallcup and Beasley, 1987) and typical morphology with few ramified processes (Figure 3A; also Figures 4 and 5; for more elaborate description see Jakovcevski and Zecevic, 2005a; Figure 2). These cells are still mitotic, so we consider them "progenitors". Later along the oligodendrocyte lineage cells are not considered to be proliferative any more, thus in this review we use the term "precursors" for these cell types. We detected the first PDGFR $\alpha$ expressing $\left(\right.$ PDGFR $\alpha^{+}$) cells in the forebrain of $10 \mathrm{gw}$ old fetus, but they appear in higher numbers only around $15 \mathrm{gw}$, when they are most numerous in the ganglionic eminences and in the cortical VZ/SVZ (Figure 4). By midgestation (19-22 gw) oligodendrocyte precursor cells invade more dorsal areas of the telencephalic wall, including the cortical plate. During the whole period of our observation (from the onset of neurogenesis, at $5 \mathrm{gw}$, until the beginning of the third trimester, $24 \mathrm{gw}$ ) early oligodendrocyte progenitors were most dense in the cortical subventricular

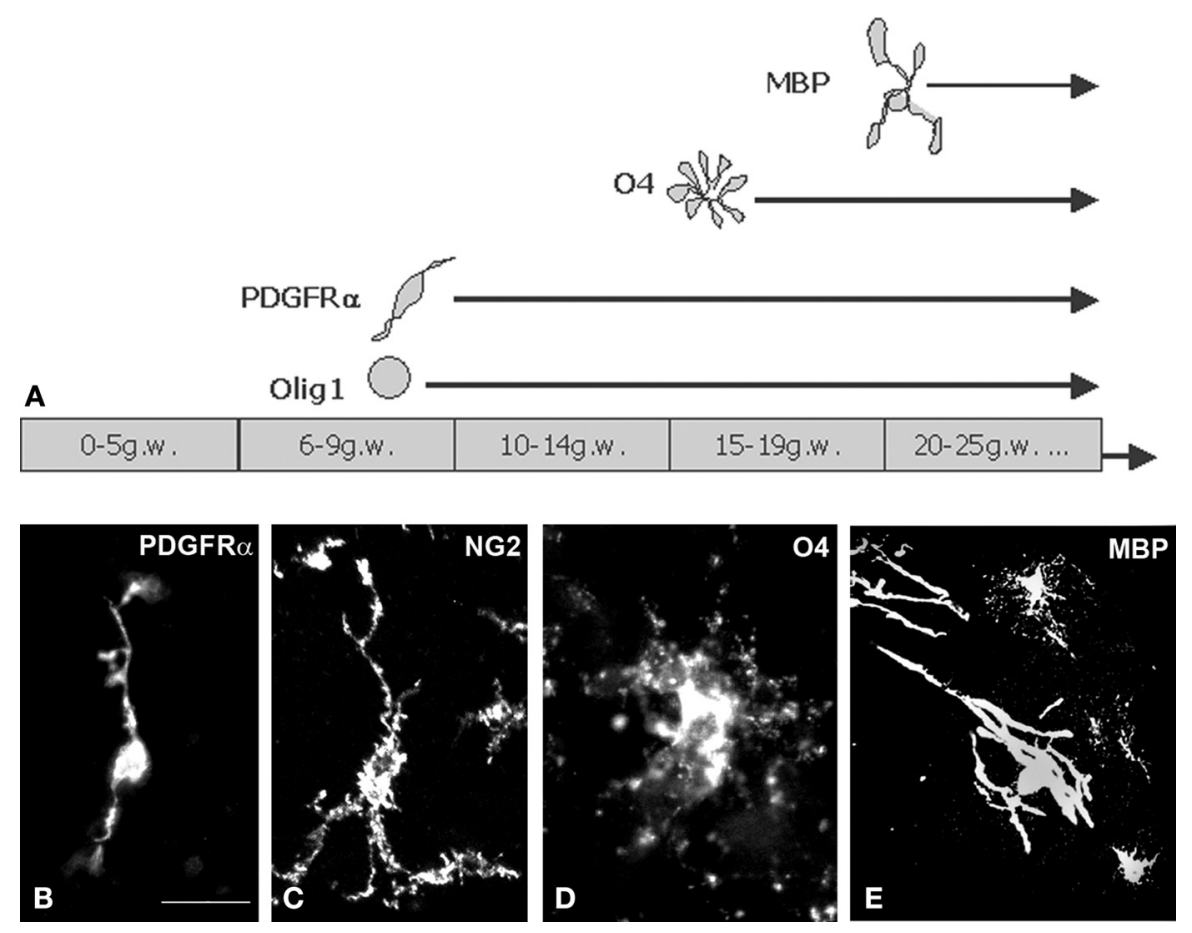

FIGURE 2 |Time-course of various oligodendrocyte lineage markers expression in the human forebrain. (A) Early oligodendrocyte precursor cells appear around $9 \mathrm{gw}$ in the ganglionic eminence, and during the next few weeks spread to cortex. Late oligodendrocyte precursors appear in modest numbers around $15 \mathrm{gw}$. $\mathrm{MBP}^{+}$cells with typical oligodendrocyte morphology are very sparse at midgestation, but their population steadily enlarges. The first myelin sheaths can be demonstrated by MBP staining at $18 \mathrm{gw}$ in thalamus, and around $21 \mathrm{gw}$ in the internal capsule. During the whole period of our observation (up to $24 \mathrm{gw}$ ) cortical white matter was not myelinated, i.e. not "white." (B-E) Examples of 3D reconstructions from serial confocal sections stained with antiPDGFR $\alpha$ (B), anti-NG2 (C), anti-O4 (D) and anti-MBP (E) monoclonal antibodies. Image on panel $\mathrm{B}$ was taken from ganglionic eminence subventricular zone at $15 \mathrm{gw}$, panels (C) and (D) from cortical subplate zone at $22 \mathrm{gw}$ and panel (E) from internal capsule, $24 \mathrm{gw}$. Scale bar: $20 \mu \mathrm{m}$. 

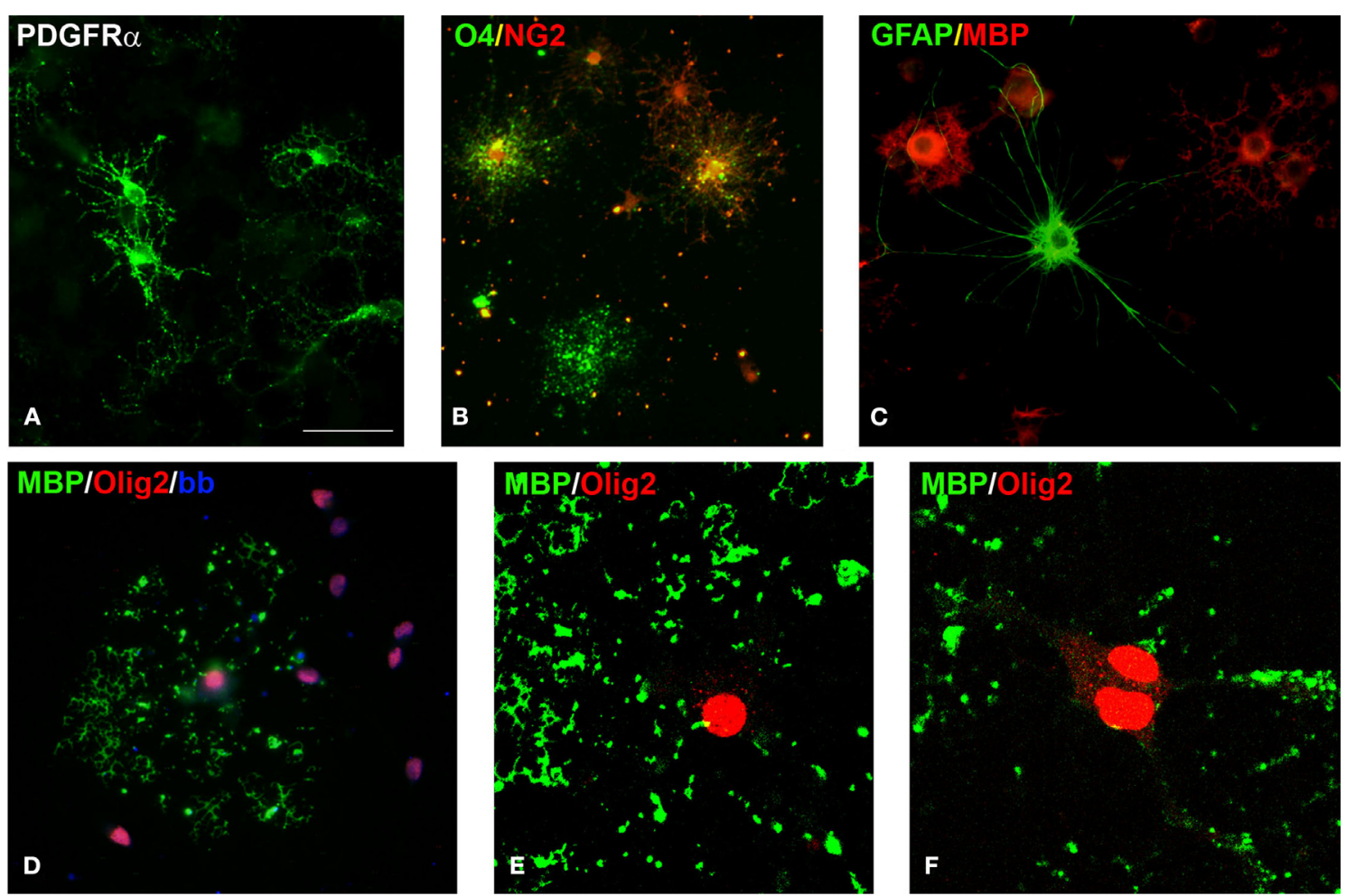

FIGURE 3 | Cells of oligodendrocyte lineage in culture. (A) Early oligodendrocyte precursors expressing PDGFR $\alpha$. (B) O4+ late oligodendrocyte precursors (green), some of them double-labeled with NG2 (yellow in overlay) and some early oligodendrocyte precursors labeled only with NG2 (red). (C) $\mathrm{GFAP}^{+}$astrocyte (green) among $\mathrm{MBP}^{+}$oligodendrocytes (red). (D) All cultured oligodendrocytes express nuclear Olig2 (red), here shown in the $\mathrm{MBP}^{+}$mature oligodendrocytes (green). (E, F) Confocal image of an oligodendrocyte with Olig2 ${ }^{+}$nucleus that produces $\mathrm{MBP}^{+}$myelin-like membrane (green). Interestingly, Olig2 expression is not localized only to the cell nucleus, but it is also seen in the cytoplasm. Scale bar: (A-D) $20 \mu \mathrm{m},(\mathbf{E}, \mathbf{F}) 10 \mu \mathrm{m}$. zone, consistent with their origin from this secondary proliferative zone in the human cortex (Jakovcevski and Zecevic, 2005a; Figures 4 and 6 ).

In the next stage in oligodendrocyte development, late oligodendrocyte precursor cells are characterized by $\mathrm{O} 4$ immunoreactivity, whereas pre-myelinating oligodendrocytes are reactive to $\mathrm{O} 1$ antibody (Figures 2D and 3B). $\mathrm{O} 4$ and $\mathrm{O} 1$ antibodies were raised against glycoproteins in the oligodendrocyte membrane and are shown to specifically label cultured late oligodendrocyte precursor cells (Bansal et al., 1989; Sommer and Schachner, 1981; Warrington and Pfeiffer, 1992). Staining of tissue sections with these antibodies is often hampered by the instability of the glycan epitopes to fixation. Earlier study on rat brain sections has shown that, indeed, it is not fixation but freezing that disperses the antigens and hampers immunostainings (Warrington and Pfeiffer, 1992). In our studies, however, we have been able to detect $\mathrm{O} 4$ and $\mathrm{O} 1$ expressing cells in human brains when we omitted detergent from the blocking solution. Similar results were reported by Back et al. (2001). In the human forebrain at midgestation (20-22 gw), we reported that $\mathrm{O}^{+}$ and $\mathrm{O}^{+}$cells are especially dense in the subplate layer, immediately bellow the cortical plate (Jakovcevski and Zecevic, 2005a; Rakic and Zecevic, 2003a). This distribution of late oligodendrocyte precursors raises a possibility that transient subplate layer is important for maturation of oligodendrocytes. This is not inconceivable, since subplate is the target of numerous afferent fibers (Kostovic and
Judas, 2002; Kostovic and Rakic, 1990) and has a rich extracellular matrix (Sheppard et al., 1991), also attracting numerous glial fibrillary acidic protein expressing astrocytes at midgestation (Zecevic, 2004). Considering the importance of transient subplate layer which receives the thalamic afferents essential for proper wiring of cortical neurons (McKellar and Shatz, 2008; Moore et al., 2008), it is tempting to speculate that oligodendrocytes come to the subplate to obtain yet unknown signals necessary for their maturation and myelination of the axons in correct sequence.

Maturation of oligodendrocytes is marked by the expression of myelin proteins, and the two major myelin proteins, myelin basic protein (MBP) and proteolipid protein (PLP), are the first to be expressed at detectable levels (Verity and Campagnoni, 1988). MBP was detected very early in human embryonic brains (around $5 \mathrm{gw}$ ), but this expression was attributed to Golli/MBP splice variants (Tosic et al., 2002; Zecevic et al., 1998). In the forebrain, first $\mathrm{MBP}^{+}$cells of typical oligodendrocyte morphology (Figures 3C-F) were found at $18 \mathrm{gw}$, around the middle of intrauterine development (Back et al., 2001; Jakovcevski and Zecevic, 2005a). $\mathrm{MBP}^{+}$cells are scattered through the intermediate zone, the future white matter, and increase in numbers with progression of development (Figure 2E; Jakovcevski and Zecevic, 2005a). Our evidence supports the ventral to dorsal progression of oligodendrogenesis, also reported in rodents (Pringle and Richardson, 1993; Timsit et al., 1995). Indeed, a ventro-dorsal 

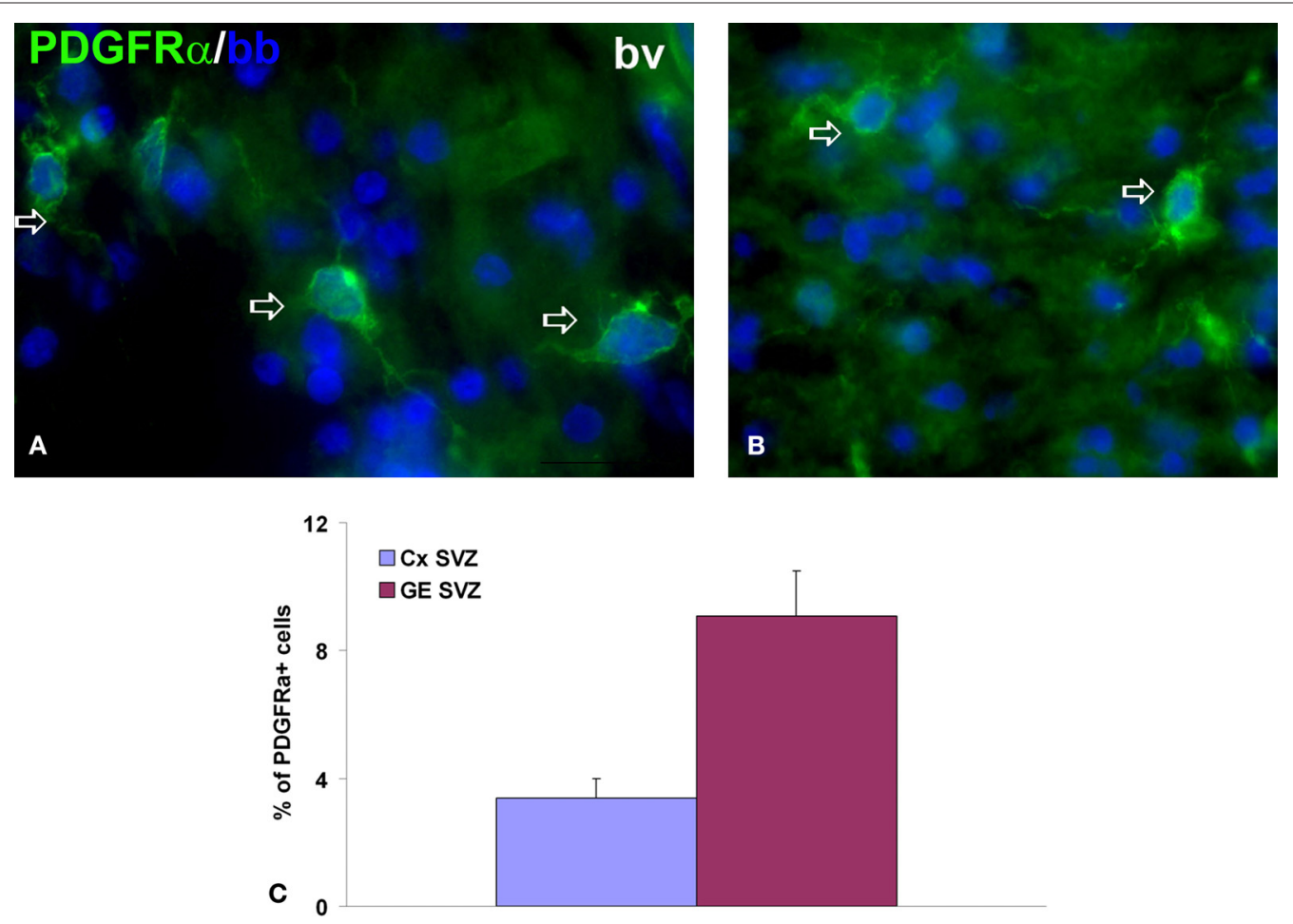

FIGURE 4 | Early oligodendrocyte progenitors in 15-week-old human forebrain. (A, B) Representative image of PDGFR $\alpha^{+}$early oligodendrocyte progenitors (green, arrows) in ganglionic eminence subventricular zone (GE SVZ,
(A)) and cortical SVZ (Cx SVZ, (B)). Nuclei are counterstained with bisbenzamide (bb, blue). (C) Proportion of PDGFR $\alpha^{+}$cells from all cells in these two regions at 15 gestation weeks. bv, blood vessel.
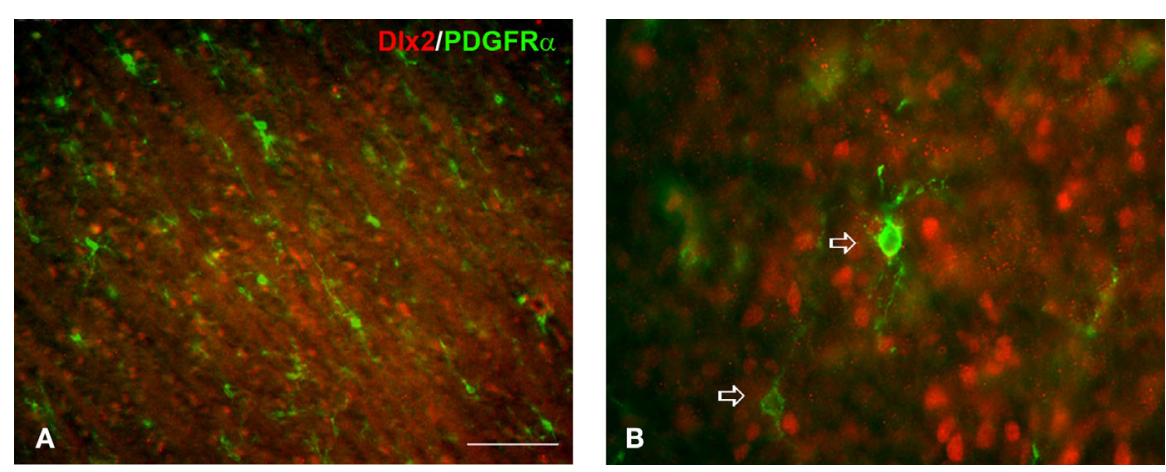

FIGURE 5 |The expression of DIx2 and PDGFR $\boldsymbol{\alpha}$ in $\mathbf{1 5}$ weeks old human fetal brain. Dlx2 (red) and PDGFR $\alpha$ (green, arrows) are usually not co-expressed in the emerging cortical white matter (A) and ganglionic eminence (B). Scale bar: $100 \mu \mathrm{m}$ (A), $20 \mu \mathrm{m}$ (B).

gradient in the extent of myelination (Jakovcevski et al., 2007) and in oligodendrocyte precursor cells density (Jakovcevski and Zecevic, 2005a,b; Rakic and Zecevic, 2003a) was seen in the human fetal forebrain.

Finally, in the rodent forebrain oligodendrocytes are initially derived from ventrally positioned ganglionic eminences (GE), whereas later they originate from the dorsal cortical subventricular zone (Kessaris et al., 2006; Marshall and Goldman, 2002). In human fetal forebrains at midgestation a subpopulation of cortical oligodendrocyte progenitor cells was expressing Dlx2 and Nkx2.1 (Rakic and Zecevic, 2003a), transcription factors specific for ventrally derived cells in rodents (Anderson et al., 1997; He et al., 2001; Marin and Rubenstein, 2001). However, as these transcription factors show a strong signal in the human proliferative zones of both GE and cortex (Rakic and Zecevic, 2003b), the origin of human Dlx2- and Nkx2.1-expressing oligodendrocyte progenitor cells could not be simply determined. Another large population of oligodendrocyte progenitor cells at this stage did not express Dlx2 and Nkx2.1 transcription factors, and could represent population of dorsally derived oligodendrocytes in the human brain (Figure 5; Rakic and Zecevic, 2003a). Yet a third population of cells co-labeled with oligodendrocyte progenitor markers (PDGFR $\alpha$, NG2, Olig1), 

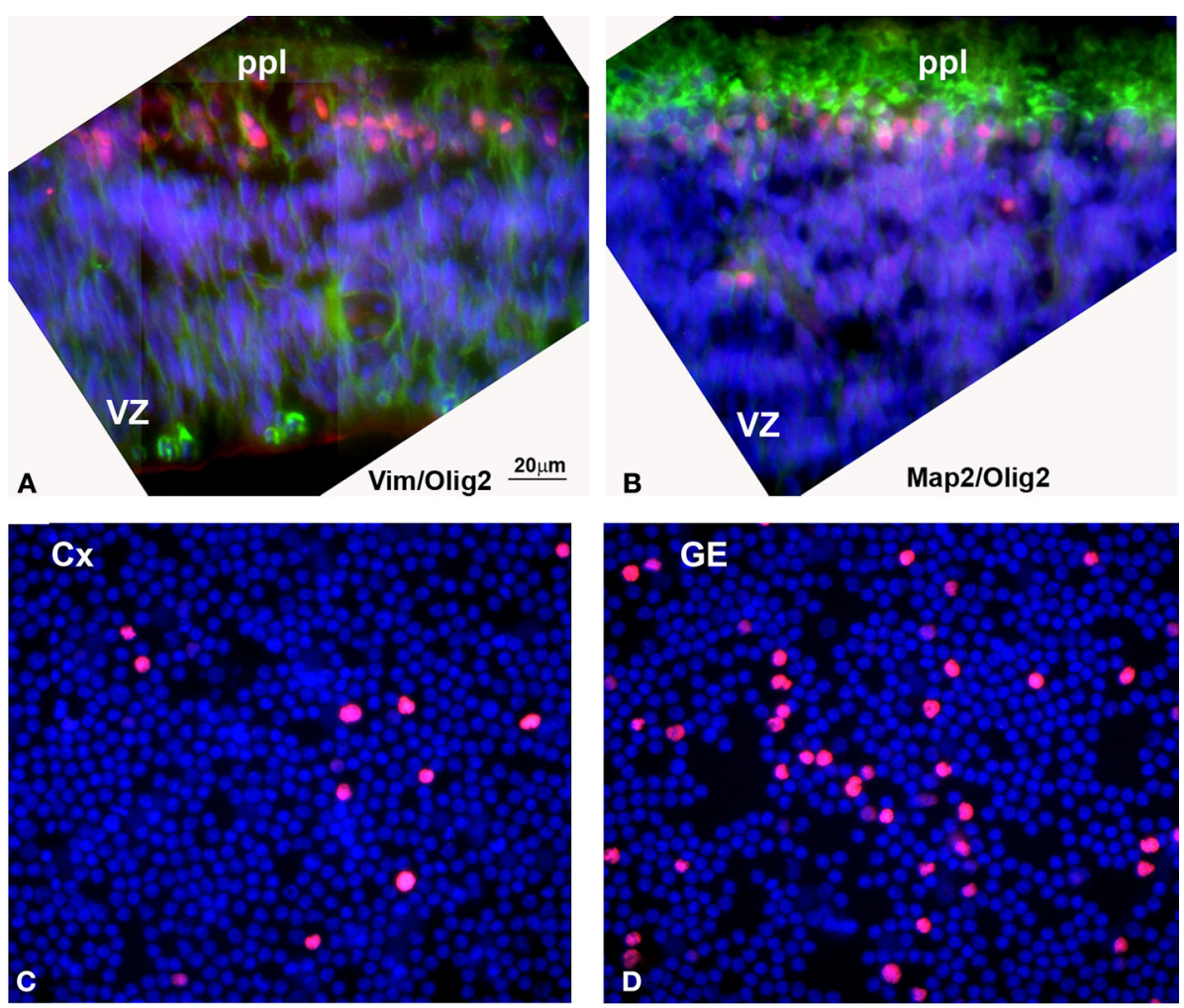

FIGURE 6 | (A, B) Olig2 expression in human embryonic (5 $\mathbf{~ g w ) ~ f o r e b r a i n . ~ ( A ) ~ O l i g 2 ~ c e l l s ~ ( r e d ) ~ i n ~ t h e ~ p r i m o r d i a l ~ p l e x i f o r m ~ l a y e r ~ ( p p l ) , ~ b u t ~ n o t ~ i n ~ t h e ~}$ ventricular zone (VZ), where vimentin ${ }^{+}$radial glia cells (green) are dividing. (B) Olig2 is expressed in nuclei of MAP2 ${ }^{+}$young neurons (green) at this stage. (C, D) Densities of Olig2 ${ }^{+}$cells (red) in the acute ( $4 \mathrm{~h}$ in vitro) dissociated cell cultures from human cortical (Cx) and ganglionic eminence (GE) ventricular/ subventricular zones at midgestation (20 gw). Nuclei are counterstained by bisbenzamide (blue). Detailed quantification was published by Jakovcevski and Zecevic (2005b).

stem cell marker nestin, and markers of cells from hematopoietic lineage (CD34, CD68) was present in what appears to be a stream of cells migrating between the ganglionic eminences and cortical subventricular zone (Rakic and Zecevic, 2003a). These combined findings suggest multiple origins of human cortical oligodendrocytes (Jakovcevski and Zecevic, 2005a,b; Rakic and Zecevic, 2003a) and have broad implications for normal brain development as well as white matter pathologies.

It is possible that oligodendrocytes derived from various sources have different roles, or myelinate different axonal pathways. This becomes especially important and demands further investigation in the light of reports that implicate oligodendrocytes in other functions in addition to "traditional" myelin formation, including synaptic regulation and signaling at the nodes of Ranvier (Bergles et al., 2000; Butt et al., 1999; Lin et al., 2005; Nishiyama et al., 2009).

\section{OLIG GENES AND THE COMMON OLIGODENDROCYTE - NEURONAL PROGENITOR CELL}

Studies of origin of oligodendrocytes in rodents have shown that ventral morphogen Shh is essential for early specification of oligodendrocyte progenitors in the neural tube (Nery et al., 2001; Tekki-Kessaris et al., 2001). Shh activates a cascade of transcription factors including Pax10, Dlx2, Nkx2, Olig1 and Olig2 (Nery et al., 2001; Pringle et al., 1996; Tekki-Kessaris et al., 2001). Olig2 was described in neural progenitors that give rise to both motor neurons and oligodendrocytes in the ventral spinal cord region (Lu et al., 2000, 2002; Takebayashi et al., 2000; Zhou et al., 2000). Olig genes belong to a bHLH group of transcription factors that are necessary and sufficient for generation of oligodendrocytes and for myelination in mice (Lu et al., 2000, 2002; Takebayashi et al., 2002; Tekki-Kessaris et al., 2001; Zhou and Anderson, 2002; Zhou et al., 2000; 2001). In the human fetal brain we demonstrated the expression of Olig2 in the ganglionic eminences and the medial cerebral cortex starting as early as $5 \mathrm{gw}$, before the onset of either neurogenesis or oligodendrogenesis (Figures 6A,B; Jakovcevski and Zecevic, 2005b). Our study also revealed that various cell types later in development express both Olig1 and Olig2. Most notably, Olig2 is expressed in all $\mathrm{MBP}^{+}$cells in the human fetal forebrain and spinal cord at midgestation, and in around $50 \%$ of early oligodendrocyte progenitors in the SVZ. At the same time and at the same location, cortical SVZ, a subpopulation of MAP2 ${ }^{+}$ neuronal progenitors is also Olig $2^{+}$. In contrast, mature neurons in the cortical plate labelled with either NeuN or GABA antibodies, do not co-express Olig2 (Jakovcevski and Zecevic, 2005b). Taken together these observations suggest existence of a common progenitor cell for oligodendrocytes and at least some neuronal classes in the human forebrain. Similar relationship was extensively reported in rodent spinal cord where oligodendrocytes and motoneurons 
develop from the same Olig2 expressing domain, as seen by various methods including Olig2-deficient mice (reviewed in Lu et al., 2002; Richardson et al., 2000; Rowitch, 2004). In the forebrain, however, the situation appears to be more complex. Common progenitor cell has been suggested for cortical interneurons and oligodendrocytes derived from ganglionic eminences (He et al., 2001), and a recent fate-mapping study shows that oligodendrocyte precursors in adult mice give rise to projection neurons in the piriform cortex (Rivers et al., 2008). On the basis of our studies of olig transcription factors' expression in the fetal human central nervous system, we propose the model linking oligodendrocyte and neuronal lineages in brain and spinal cord through common Olig2-expressing progenitors (Figure 7).

Genetic mapping and heterologous transplantation fate mapping studies in mice have shown that Olig2 domain within medial ganglionic eminence gives rise to cortical interneurons (Butt et al., 2005; Miyoshi et al., 2007). There is, however a controversy about the necessity of Olig2 for cortical interneuron fate determination. When Olig2 was ablated from cortical progenitors no change in interneuronal populations was observed (Miyoshi et al., 2007). One possible explanation for this finding could be that other bHLH genes, like Olig1, compensate for it. In our study we found Olig1 colocalized in vimentin-expressing cortical radial glia cells, a cell type demonstrated to be a multiple neural progenitor (Mo and Zecevic, 2009; Mo et al., 2007). We have no evidence that in human brain Olig1 is co-expressed in neuronal populations, but that does not preclude the possibility that by the time neurons acquire their fate this gene gets down-regulated (Jakovcevski and Zecevic, 2005b). This inability to draw conclusions about temporal developmental events is an intrinsic limitation of all studies on fixed human tissue, and is the most important reason why we resorted to different in vitro systems.

In vitro, Olig2 plays a role in self-renewal of mouse neurosphere cultures, and in differentiation of neurons and oligodendrocytes in

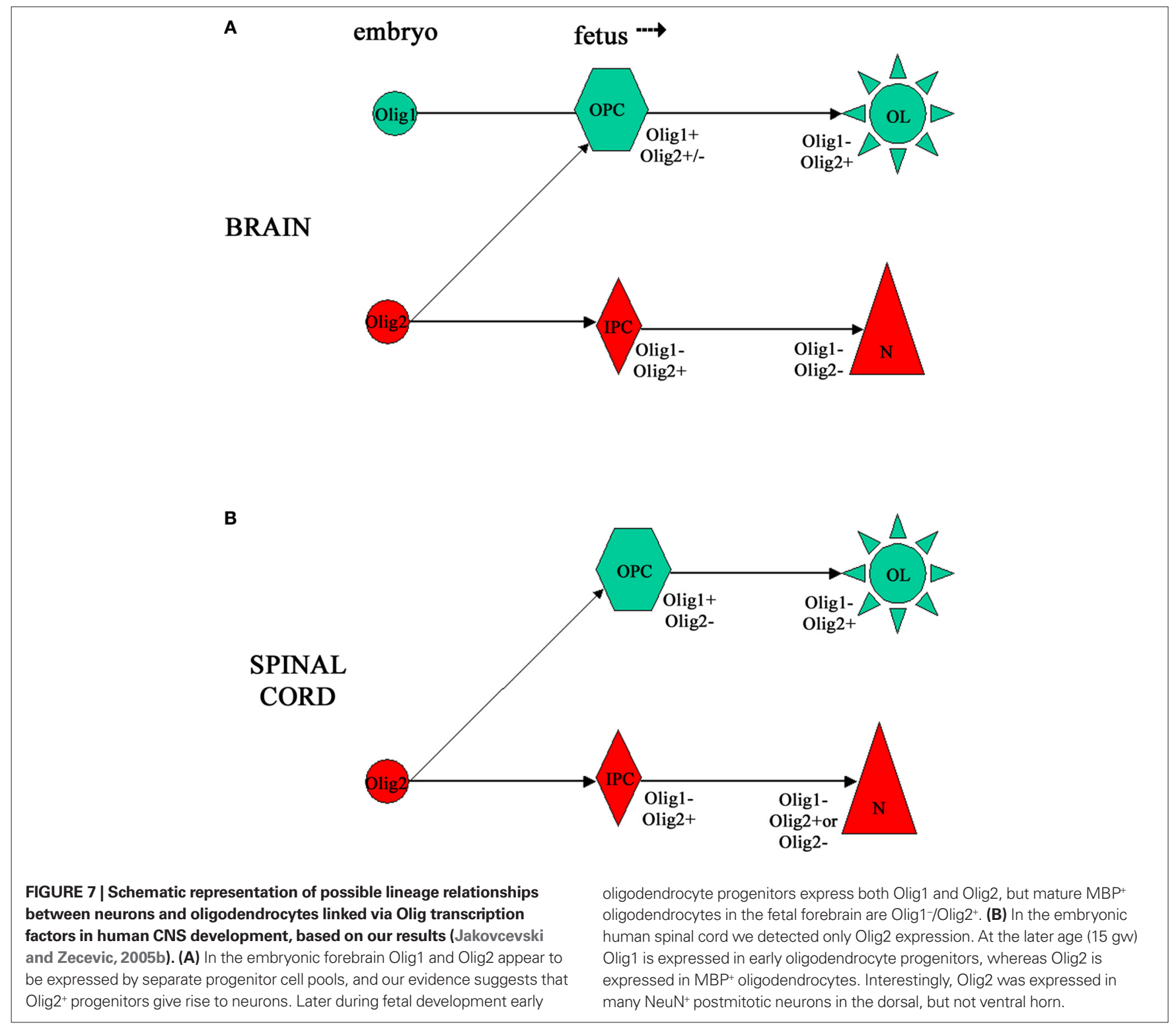


appropriate condition media (Hack et al., 2004). In cultures with growth factors (FGF2 and EGF), Olig2 was expressed in almost all progenitors derived from mouse ganglionic eminences or cortex, whereas dorsal transcription factors, Pax6 and Emx1, were downregulated (Hack et al., 2004). In contrast, in cryosections of human lateral ganglionic eminence at 15-20 gw, Olig2 and Pax6 were coexpressed in the same progenitor cells. This finding was extended to cell cultures from cortical VZ/SVZ. Co-expression of these two transcription factors in dividing progenitor cells is consistent with an increased complexity of human neural progenitor cells in comparison to other mammals (Mo and Zecevic, 2008).

\section{RADIAL GLIA DERIVED SUBPOPULATION OF FOREBRAIN OLIGODENDROCYTES}

As has been discussed above, we reported that in the VZ/SVZ of the fetal forebrain, cells occasionally co-express radial glia cells markers and oligodendrocyte lineage markers, suggesting lineage relationship (Jakovcevski and Zecevic, 2005a,b). Radial glia are multipotent progenitor cells in rodents, generating projection neurons (Miyata et al., 2001,2004; Noctor et al., 2001) and a subpopulation of forebrain oligodendrocytes (Casper and McCarthy, 2006; Malatesta, et al., 2003). Similar to these findings, radial glia cells are also neuronal and oligodendrocyte progenitor cells in human fetal brain (Mo and Zecevic, 2009; Mo et al., 2007). In vivo loss- and gain-of-function studies that are successfully used in animal models to show linage relationship are not possible in humans. To study cortical neural progenitors and their progeny, we established an in vitro system with human fetal brain tissue. This approach enabled us to use some of experimental methods not commonly applied to human brain. For example, the Cre/loxP co-transfection was used to study the relationship of two cell types: radial glia and oligodendrocytes. We first isolated human fetal radial glia in culture and then transfected them with a BLBPCre/Floxed-YFP to study cell fate of their progeny. Thus, specificity of BLBP (brain lipid binding protein) plasmid to radial glia cells was combined with YFP (yellow fluorescent protein) reporter signaling related to $\beta$-actin-like promoter that remains active in cells after differentiation. The Cre/loxP method made it possible to see the progeny of $\mathrm{BLBP}^{+}$radial glia even after BLBP expression was downregulated during cell differentiation to another cell type (Mo and Zecevic, 2009; Mo et al., 2007). As we expected from the initial findings of double-labeled cells in cryosections of fetal forebrain, in vitro results directly demonstrated that a small subset of fetal radial glia cells differentiates along oligodendrocyte linage following the same path as described in vivo (Jakovcevski and Zecevic, 2005a). Transfected cells expressed first NG2 and O4 (Figure 8), and subsequently markers and morphology of premyelinating oligodendrocytes labeled with MBP and MOG (myelin oligodendrocyte glycoprotein) (Figure 5 in Mo and Zecevic, 2009).

We further demonstrated that this in vitro generation of oligodendrocyte progenitors from isolated radial glia cells was under Shh influence. This is not surprising considering a well-described role of this morphogen in brain development in rodents (Nery et al., 2001; Tekki-Kessaris et al., 2001). However the role of Shh in normal human forebrain development, and specifically in dorsal oligodendrogenesis, is less well documented. From this aspect, our finding that radial glia enriched from cortical VZ/SVZ of midgestational (20 gw) fetuses expressed both Shh receptors, Ptcl (patched) and

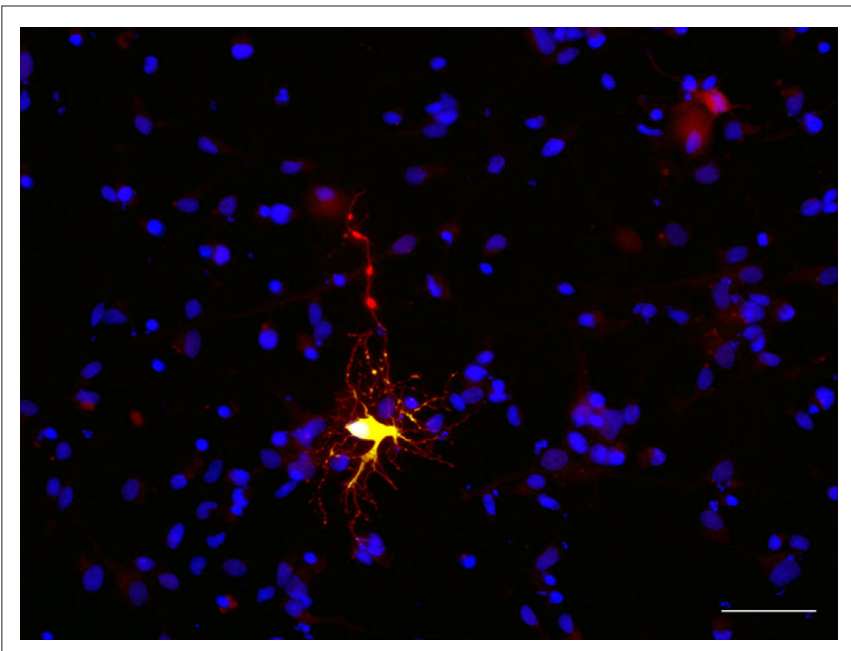

FIGURE 8 | Human fetal radial glia cell in culture differentiates as an oligodendrocyte progenitor. BLBP-Cre/Floxed-YFP transfected cell (green) co-labeled with $\mathrm{O} 4$ (red) after 7 days in culture. Scale bar: $20 \mu \mathrm{m}$.

Smo (smoothened), was consistent with the idea that Shh influences human forebrain development in a similar way that was reported in rodents. We found that adding Shh in culture of radial glia cells, increased the number of generated $\mathrm{O}^{+}$oligodendrocyte precursor cells, whereas adding Shh inhibitor, cyclopamine reduced the number of $\mathrm{O}^{+}$cells in these cultures. Taken together these findings support the idea that Shh usually thought of as a ventral morphogen, also may play a role in dorsal oligodendrogenesis in human forebrain.

Dorsal transcription factor Pax6 has been reported to be important for generation of neurons in rodents (Götz et al., 1998; Heins et al., 2002), and also in humans (Mo and Zecevic, 2008). Pax6 however may also have a role in oligodendrogenesis (Mo and Zecevic, 2008). Other transcription factors, such as Olig1 and Olig2 may be necessary to specify radial glia as oligodendrocyte progenitors. Indeed we have observed that Olig1 and Olig2 can be co-expressed with radial glia marker vimentin along the ventricular zone at $15 \mathrm{gw}$ (Mo and Zecevic, 2009). It would be important to determine whether a majority or only a specific subtype of human oligodendrocytes is generated from radial glia cells and whether radial glia are the only early oligodendrocyte progenitors in the cortical VZ/SVZ. Alternatively radial glia cells could generate oligodendrocytes only at a specific developmental stage or at a particular brain region, such as cortical VZ/SVZ. However, without careful quantification on a larger sample size, we do not know how widespread these phenomena are. Equally unknown is how they change during the span of development? This is particularly important to establish, since developmental potential of progenitor cells becomes more and more restricted over time.

\section{ASTROCYTE-OLIGODENDROCYTE INTERACTIONS DURING OLIGODENDROCYTE DEVELOPMENT}

Formation of myelin during primary myelination and its restoration in remyelination, involves proliferation, migration and differentiation of oligodendrocyte progenitors into myelin-forming oligodendrocytes. Growth factors, cytokine members of the interleukin (IL) superfamily, chemokines, such as growth-related oncogene alpha (GRO- $\alpha$ ) also referred to as CXCL1, and other 
mediators influence oligodendrocyte progenitor cells proliferation and/or differentiation, and are also very important for remyelination (e.g. Dubois-Dalcq and Murray, 2000; Gard and Pfeiffer, 1993; Grinspan, 2002; Mason et al., 2003; Ransohoff et al., 2002; Wilson et al., 2003). Moreover, it has been demonstrated that this chemokine is upregulated during experimental autoimmune encephalomyelitis (EAE) (Glabinski et al., 2000) and around lesions in multiple sclerosis (Filipovic et al., 2002, 2003; Omari et al., 2005, 2006). We studied the distribution of chemokine CXCL1 and its receptor CXCR2 in human developing forebrain, and reported that it is highly expressed in cortical VZ/SVZ (Filipovic et al., 2003) in accord with an earlier study in rodents (Robinson and Franic, 2001). The SVZ is one of the largest proliferative regions with multiple progenitor classes in developing rodent (Lachapelle et al., 2002; Luskin, 1993) and human brain (Rakic and Zecevic, 2003a,b; Sanai et al., 2004; Zecevic et al., 2005). The SVZ in adult brain is also a source of newly generated oligodendrocytes in MS (Nait-Oumesmar et al., 2007). In rats, CXCL1 induces proliferation of oligodendrocyte progenitors and limits their migration (Robinson et al., 1998). The fact that human and rodent oligodendrocyte progenitors differently respond to various mitogens (Armstrong et al., 1992; Scolding et al., 1995; Wilson et al., 2003; Zhang et al., 2000) led us to explore the role of CXCL1 in the human fetal forebrain. Moreover, we were intrigued by the finding that during midgestation very few oligodendrocyte progenitors express CXCR2 receptor (Filipovic et al., 2003). Our data suggested that if this chemokine has a role in proliferation of oligodendrocyte progenitor cells, it may exert its action trough other cell types present in the brain. To study cellto-cell interactions we used organotypic slice cultures from cortical VZ/SVZ zones and demonstrated that proliferation of human fetal oligodendrocyte progenitor cells is indeed dependent on CXCL1/ CXCR2 signaling (Filipovic and Zecevic, 2008). Moreover, we identified that this cell signaling involves the activation of the ERK1/2 pathway and release of IL-6 from astrocytes. Notably, when astrocytes are stimulated with CXCL1, they secrete IL-6, which in turn acts on oligodendrocyte progenitors and induces their proliferation (Filipovic and Zecevic, 2008). Thus, we demonstrated that in contrast to rodents where CXCL1 directly induces oligodendrocyte proliferation (Robinson et al., 1998), in human fetal brain CXCL1 has an indirect effect, acting through astrocyte secretion of IL-6, to increase oligodendrocyte proliferation.

At this point it became important to determine whether CXCL1 promotes only proliferation or affects also differentiation of oligodendrocyte progenitors. To study this, we treated human fetal slices, isolated from midgestational VZ/SVZ, with CXCL1 (10 ng/ $\mathrm{ml}$ ) for various lengths of time $(12,24$, or $48 \mathrm{~h})$. After treatment the number of $\mathrm{MBP}^{+}$premyelinating oligodendrocytes was quantified in these brain slices. Although the number of $\mathrm{MBP}^{+}$cells increased gradually, it was still not significantly different than in control slices. However, when slices treated with CXCL1 (10 ng/ $\mathrm{ml}, 48 \mathrm{~h}$ ), were cultured for additional 1 or 3 days, the number of $\mathrm{MBP}^{+}$oligodendrocytes was significantly higher than in controls slices, suggesting a delayed action of CXCL1 on differentiation of oligodendrocyte progenitors (Figure 9A). To better assess differentiation of oligodendrocytes, we calculated a differentiation index, defined as the ratio between $\mathrm{MBP}^{+}$cells and the sum of $\mathrm{MBP}^{+}$and PDGFR $\alpha^{+}$cells. A higher value of the differentiation index indicates more advanced differentiation of oligodendrocyte progenitors (Sakurai et al., 1998). In the first $48 \mathrm{~h}$ in vitro, CXCL1 treated slices had lower differentiation index than the control ones $(0.17 \pm 0.02$ vs. $0.24 \pm 0.03, n=3, P<5)$, while at 5 days the differentiation index was significantly higher in treated slices than in the controls $(0.6 \pm 0.07$ vs. $0.4 \pm 0.05, P<0.05)$. Moreover, at 5 days in vitro $\mathrm{MBP}^{+}$oligodendrocytes in treated slices had longer and more branched processes as compared to controls (Figures 9D,E). Western blots revealed increased levels of MBP after CXCL1 treatment, as compared to controls (Figure 9I). In contrast, in the presence of either the CXCR2 antagonist (100 nM, $24 \mathrm{~h}$ ) or after blocking ERK1/2 activation with PD98059 $(50 \mu \mathrm{M}, 24 \mathrm{~h})$, the number of $\mathrm{MBP}^{+}$oligodendrocytes was significantly decreased (Figure 9B). Taken together these results confirmed the role of CXCL1 not only in proliferation, but also in oligodendrocyte differentiation.

To test if this positive effect was due to secreted factors from different cell types, we isolated the effect of microglia and astrocytes by selectively eliminating each cell type with appropriate toxins (Filipovic and Zecevic, 2008). We collected conditioned media from these cell type specific cultures, and treated slices with either astrocyte or microglia conditioned media for $24 \mathrm{~h}$. Four days later the number of $\mathrm{MBP}^{+}$oligodendrocytes was quantified. Only the conditioned medium from CXCL1 treated astrocytes (CXCL1-ACM) increased the number of $\mathrm{MBP}^{+}$oligodendrocytes, as compared to control media. In contrast, the number of $\mathrm{MBP}^{+}$oligodendocytes significantly declined when ERK1/2 or IL-6 were blocked (Figure 9C). In addition, blocking of either CXCR2, ERK1/2 activation or IL-6 release from astrocytes, changed the morphology of $\mathrm{MBP}^{+}$cells, which exhibited less elaborate processes (Figures 9F-H).

This finding supported our hypothesis that the CXCL1/ ERK1/2/IL-6 pathway had an important role in oligodendrocyte progenitor proliferation and their subsequent differentiation into premyelinating oligodendrocytes. In the absence of microglia or astrocytes, $\mathrm{MBP}^{+}$oligodendrocytes had less branched processes and their number was reduced as well. Similar to findings on proliferation, the differentiation of oligodendrocyte progenitors was decreased by neutralization of IL-6, but not of CXCL1 secreted from astrocytes (Figure 9C). We propose that a novel interaction between astrocytes and oligodendrocytes, the one that includes CXCL1/IL-6 signaling pathway, enhances development of human fetal oligodendrocytes.

During remyelination in MS, basic processes of oligodendrocyte development including proliferation, migration and differentiation of oligodendrocytes progenitors are recapitulated. For that reason it is of extreme importance to understand processes during normal oligodendrogenesis. We describe here that constitutive expression of CXCL1 has physiological relevance, whereas exogenous CXCL1 might be relevant in pathological conditions, such as developmental disorders of white matter, or in MS. This is supported by the finding that CXCL1 is abundant around MS lesions (Filipovic et al. 2002, 2003), the site where attempts of remyelination are found (Chang et al., 2002; Franklin, 2002; Levine et al., 2001; Raine et al., 1981;Wolswijk, 1998). We discovered that CXCL1 acts in synergy with IL-6. The function of IL-6 is not well understood, but it was reported to range from protracting relapses (Diab et al., 1997) to limiting demyelination in EAE (Di Marco et al., 2001; Willenborg et al., 1995). Future studies should address the role of this pathway 

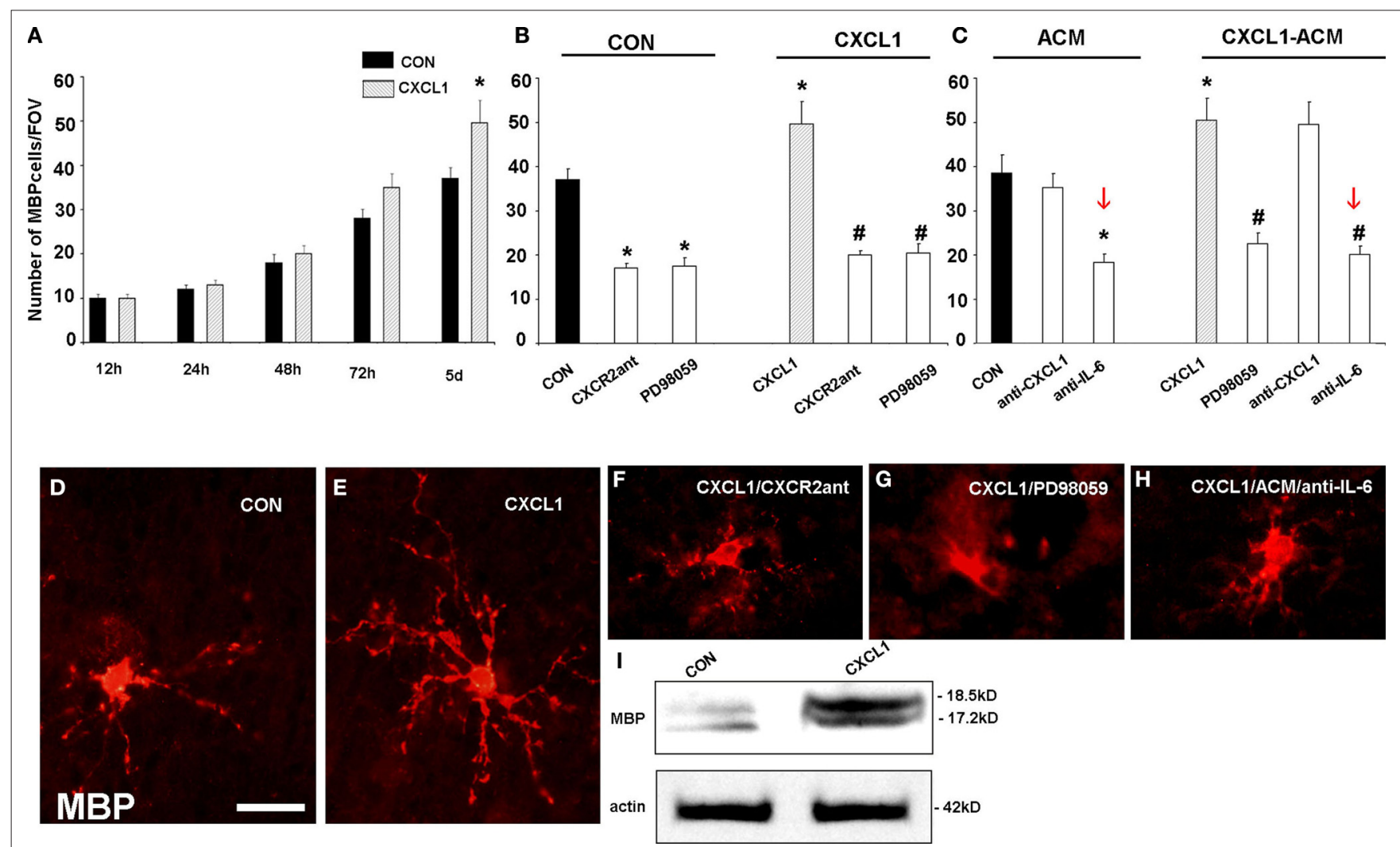

FIGURE 9 | Effect of CXCL1 on the differentiation of oligodendrocyte progenitors in slice cultures from VZ/SVZ region at midgestation. (A) Timedependent effect of CXCL1 on the number of $\mathrm{MBP}^{+}$oligodendrocytes (OLs) per field of view (FOV). OL number is significantly different between control (CON) and CXCL1 treated slices after $5 \operatorname{div}\left(n=7,{ }^{*} P<0.05\right.$ vs. control slices) (B, C) The number of OLs in different experimental conditions after $120 \mathrm{~h}$ in vitro.

(B) Decreased number of OLs is observed after inhibition of CXCR2 receptor or ERK1/2 pathway in CON and CXCL1 treated slices ( $n=7,{ }^{*} P<0.05$ vs. controls, ${ }^{\#} P<0.05$ vs. CXCL1 treated slices). (C) Treatment of slices with CXCL1 stimulated astrocyte conditioned medium (CXCL1/ACM) significantly increases the number of OLs, as compared to conditioned medium from unstimulated astrocytes (ACM). Reduced number of OLs cells is observed after ERK1/2 inhibition, or after neutralization of IL-6, in ACM or in CXCL1-ACM. ( $n=3, P<0.05$ vs. ACM; ${ }^{P} P<0.05$ vs. CXCL1-ACM). Error bars indicate SEM. (D-H) The morphology of $\mathrm{MBP}^{+}$cells in the different conditions at 5 div. (D) $\mathrm{MBP}^{+}$ oligodendrocytes in control slices. (E) OLs with multiple processes after CXCL1 (10 ng/ml, 48 h) treatment. (F, G) OLs have fewer and shorter processes after CXCL1 treatment in a presence of CXCR2 antagonist (100 nM, 24 h) or PD98059 (50 $\mu \mathrm{M}, 24 \mathrm{~h})$, (H) Similar morphology is obtained when IL-6 is neutralized in CXCL1-ACM. (I) Western blot demonstrating upregulation of MBP (18.5 kD and $17 \mathrm{kD}$ isoforms) in CXCL1 (10 ng/ml, $48 \mathrm{~h}$ ) treated cultures after 5 div. Equal loading of proteins is confirmed by actin. Scale bar: in (D) for (D-H), $20 \mu \mathrm{M}$. in disorders of the white matter during normal human brain development.

\section{AXONAL SIGNALING AND MYELINATION IN THE HUMAN FETAL BRAIN}

A wide variety of signals that may be involved in initiation of myelination of CNS axons has been reported. Although mouse oligodendrocytes in vitro have the capacity to form myelin-like membranes in the absence of neurons (Temple and Raff, 1986), co-culture with neurons significantly increases MBP gene expression in these cultures (Macklin et al., 1986), suggesting that axons are necessary for efficient myelination. In vivo experiments in the rat optic nerve demonstrated that oligodendrocyte proliferation and subsequent myelination depend on the electrical activity in axons (Barres and Raff, 1993). Other studies have confirmed that ion channel activation or electrical activity in axons can regulate myelination (Demerens et al., 1996; Ishibashi et al., 2006; Stevens et al., 1998), suggesting that oligodendrocytes preferentially myelinate axons which fire action potentials. This is not surprising, considering that the most important role of myelin sheath is to provide saltatory conduction of action potentials.

Myelination in the human brain progresses over several decades, which is much longer than a complete lifespan of the commonly studied animals. Recently emerged data suggest that myelination may play an important role in data processing by neurons (Fields, 2008). On the one hand, it is now clear that human white matter changes with experience, i.e. that myelinating glia respond to environmental cues, as shown by magnetic resonance imaging of neglected children (Teicher et al., 2004). On the other hand, myelin thickness influences conduction velocity, which is in turn instrumental in regulation of synchronous firing of action potentials and proper function of the brain (Fields, 2008).

Finally, several myelin proteins, including Nogo-A, MAG and MOG cause the growth-cone collapse that prevents axons from reaching their targets (for review see Filbin, 2003). This feature of myelin is now appreciated as an important regulatory mechanism to suppress sprouting and formation of abnormal connections in development (Huang et al., 2005). It is thus essential to understand 
cues and signals that oligodendrocytes need to initiate unsheathing of axons in order to get insight into normal organization, and especially disorders of the human brain. Several uniquely human diseases, including multiple sclerosis and psychiatric disorders are linked to defects in myelination (Aston et al., 2005; Franklin, 2002; Georgieva et al., 2006; Tkachev et al., 2003; Trapp and Nave, 2008).

Before myelination is initiated, oligodendrocyte precursors transform first to pre-myelinating oligodendrocytes and then into mature myelin-producing cells (Pfeiffer et al., 1993). During this process, myelin proteins, MBP and PLP, shift their expression from cell bodies to processes that form myelin sheaths (Hardy and Reynolds, 1991). In humans there is a clear dissociation between the time of oligodendrocyte differentiation and the beginning of myelination in the fetal forebrain (Back et al., 2001; Jakovcevski and Zecevic, 2005a). Pre-myelinating oligodendrocytes ( $\mathrm{Ol}^{+}$cells) were present already at the beginning of midgestation (17-20 gw). The onset of myelination, however, was described only several months later, during the last trimester, first in the basal ganglia and somewhat later in the corpus callosum (Back et al., 2001; Jakovcevski et al., 2007; Ulfig et al., 1998). Biochemical methods, such as detection of sulfatide by thin-layer chromatography and detection of MBP by SDS-PAGE, showed compact myelin in the human forebrain only after birth (Kinney et al., 1994).

We observed that the number of $\mathrm{MBP}^{+}$oligodendrocytes dramatically increased in slice cultures of the human fetal forebrain, in comparison with their number in the frozen sections of the same fetal brains. Moreover, $\mathrm{MBP}^{+}$cells in cultures appeared to be forming myelin sheaths (Jakovcevski and Zecevic, 2005a; Jakovcevski et al., 2007). This may be attributed to the lack of inhibition of the oligodendrocyte differentiation in culture conditions and/or the presence of growth factors in the culturing medium. To explore the first possibility, we demonstrated that a prominent increase in myelination coincided with the down-regulation of a polysialic acid conjugated form of the neural cell adhesion molecule (PSANCAM). This finding is consistent with the notion that a PSAmediated signaling mechanism might be one of the regulators of primary myelination in the human fetal brain (Jakovcevski et al., 2007). Notably, in multiple sclerosis patients, axons that fail to regenerate myelin sheathes, also re-express PSA-NCAM (Charles et al., 2002). There are, however, reports that in experimental CNS regeneration paradigms PSA promoted myelination (Mehanna et al., 2009; Papastefanaki et al., 2007). This indicates that a negative correlation between PSA-NCAM and myelination may be development-specific, and dependent on the context in which myelination occurs.

It is important to stress that PSA-NCAM is not the only cell adhesion molecule to be implicated as an axonal inhibitor of primary myelination. Many other molecules, for example neural adhesion molecule L1, have been shown to be downregulated from axonal surface upon the onset of myelination. Furthermore, interfering with L1 prior to myelination onset inhibited myelination (Barbin et al., 2004). This suggests that adhesion molecules are an important signal during initial contact between axon and oligodendrocyte, but their downregulation is needed for myelination to proceed. Other types of molecules that are inhibitory for myelination comprise oligodendrocyte myelin proteins and their receptors. For example the Nogo-receptor interacting protein, LINGO-1, expressed by both axons and oligodendrocytes, negatively regulates myelination and its antagonist promoted spinal cord remyelination in the EAE model of MS (Mi et al., 2005, 2007).

Inhibitory signals in the brain act not only through cell-to-cell interactions, but also could travel through the cerebrospinal fluid and the circulation, and thus are absent from the slice culture. Supporting this notion, although Nkx2.1- and Shh-deficient mice lack mature oligodendrocytes, the cell cultures from these animals produce sufficient numbers of pre-myelinating oligodendrocytes (Nery et al., 2001). This indicates that inhibitors present in vivo are lost when cells are grown in culture. The existence of possible inhibitors of myelination during normal development has great clinical importance, since the observed lack of functional remyelination in the MS plaques may be due to specific inhibition of oligodendrocyte differentiation, despite the fact that oligodendrocyte precursors are present in and around the lesions (Chang et al., 2002; Filipovic et al., 2002; Levine et al., 2001; Scolding et al., 1998).

\section{OLIGODENDROCYTE DEVELOPMENT: RODENT VS. HUMAN}

Since most studies of mammalian brain development are done on rodents, we find it useful to understand how various time-points in rodent brain development correlate with much longer human brain development. In the literature there are just a few attempts to relate processes during rodent brain development with those in humans (Bayer et al., 1993; Clancy et al., 2007; Verley, 1977). Previous attempt to draw parallels between development of experimental animals and humans resulted in designation of Carnegie stages (O'Rahilly, 1979). This classification is based on somatic morphology of embryos and it presumes that brain development is linearly predictable from somatic development, and that all brain regions develop at equivalent rates across species. Other attempts were done to make rat/primate comparisons based on neuroanatomy, comparing rat embryonic days 11-21 with human weeks 4-16 (Bayer et al., 1993). However, most of these comparisons do not take into account disparities in relative sizes of human brain regions. After a closer examination of our schematics of oligodendrocyte lineage markers expression during human development given in Figure 2, it is clear that comparisons between human and rodent brains are neither easy to make, nor linear. Studies of human brain development from our laboratory suggest that processes like neurogenesis and oligodendrogliogenesis progress at different pace in the human brain, so every process has to be compared separately. Whereas neocortical neurogenesis does begin at $5 \mathrm{gw}$, corresponding to mouse embryonic day 10 , the ending of neurogenesis is not that clear, since at the last time-point of our study, $24 \mathrm{gw}$ neurons are still being born out of cells isolated from the cortical VZ/SVZ (Mo et al., 2007; 2008). Cortical oligodendrogenesis begins around $10 \mathrm{gw}$ in humans, but it progresses well into adulthood in humans (Yakovlev and Lecourse, 1967). Based on the expression of markers of oligodendrocyte lineage, we will try to draw parallels between human and mouse development, focusing on the forebrain. PDGFR $\alpha$ mRNA in the mouse brain was first detected at embryonic day 15 (E15), reached a peak at postnatal day 14 (P14), and fell to lower levels in adults (Yeh et al., 1993). In contrast, mRNA for MBP was detected later, at P3-P4 in the mouse corpus callosum and the internal capsule, respectively 
(Verity and Campagnoni, 1988). MBP expression reaches peak in the mouse cortical and subcortical white matter at P20, when primary myelination is completed (Campagnoni and Macklin, 1988; Verity and Campagnoni, 1988). In the human forebrain, the first early oligodendrocyte progenitors appear at $10 \mathrm{gw}$, which then can be compared to E15 in mice. The first $\mathrm{MBP}^{+}$premyelinating oligodendrocytes are detected at $18 \mathrm{gw}$ in humans, which then is comparable to P3 mouse (Figure 2). Our observations on early oligodendrocyte development and myelination onset, however, roughly fit into the previously proposed model of human-to-rodent development comparison (Bayer et al., 1993). Subsequently human primary forebrain myelination takes decades, compared to weeks in rodents (Yakovlev and Lecourse, 1967). The most important reason for this prolonged development is that much larger human brain has entire neocortical regions which rodent brains completely lack, whereas some of the key regions of rodent brains are in human relatively underdeveloped (e.g. olfactory bulbs).

Another interesting issue is concerning the overall number of oligodendrocytes in human versus rodent brain. Although numbers of oligodendrocytes needed to myelinate large human brains are much higher than in rodents, it is not as clear if the densities and proportions of oligodendrocytes are different. In mouse cerebral and cerebellar cortex, for example, the density of oligodendrocytes was estimated to be $12.5 \times 10^{3} / \mathrm{mm}^{3}$, which makes for approximately $5 \%$ of all cells detected by the nuclear staining (Irintchev et al., 2005; Jakovcevski et al., 2009). Comparable stereological studies of the human prefrontal cortex suggest very similar densities for oligodendroglia in humans (Ongur et al., 1998; Stark et al., 2004). These studies also demonstrated decreased density of oligodendrocytes

\section{REFERENCES}

Anderson, S.A., Eisenstat, D.D., Shi, L., and Rubenstein J. L. (1997). Interneuron migration from basal forebrain to neocortex: dependence on Dlx genes. Science 278, 474-476.

Armstrong, R.C., Dorn, H.H., Kufta, C. V., Friedman, E., and Dubois-Dalcq, M. E. (1992). Pre-oligodendrocytes from adult human CNS. J. Neurosci. 12, 1538-1547.

Aston, C., Jiang, L., and Sokolov, B. P. (2005). Transcriptional profiling reveals evidence for signaling and oligodendroglial abnormalities in the temporal cortex from patients with major depressive disorder. Mol. Psychiatry 10, 309-322.

Back, S. A., Luo, N. L., Borenstein, N. S., Levine, J. M., Volpe, J. J., and Kinney, H. C. (2001). Late oligodendrocyte progenitors coincide with the developmental widow of vulnerability for human perinatal white matter injury. J. Neurosci. 21, 1302-1312.

Bansal, R., Warrington, A. E., Gard, A. L., Ranscht, B., and Pfeiffer, S. E. (1989). Multiple and novel specificities of monoclonal antibodies O1, O4 and $\mathrm{R}-\mathrm{mAb}$ used in the analysis of in patients with schizophrenia and mood disorders (Ongur et al., 1998; Stark et al., 2004).

In conclusion, greater complexity of the human brain, including its longer development, larger size, and the existence of unique regions and functions, as well as uniquely human pathologies calls for more studies on human brain development. The fact that many more oligodendrocytes need to be generated to myelinate a huge amount of axons in the large white matter of the human brain, supports the idea that oligodendrocytes may be generated for a longer time period and also from various progenitor sources than in the far smaller rodent brain. Inter-species differences, thus, should be taken into consideration when extrapolating results from animal models to primate and particularly human brain. The main difficulty in conducting studies on human brain development is the limited source of human brain tissue, but hopefully this will change with more groups working in the field of human development enabling easier comparisons of results (e.g. Bayatti et al., 2008; Fertuzinhos et al., 2009; Petanjek et al., 2008; Stillman et al., 2009). Another promising new direction is the use of human embryonic stem cells-derived tissues that would allow in vitro studies of developmental processes on a much larger scale and in a more reproducible manner.

\section{ACKNOWLEDGEMENTS}

This work was supported by NIH NS041489-09 and Soc for MS grant RG 3083C4/1 to NZ. We are thankful to Dr. David Hunt for editing English. Authors owe a special debt to Dr. Bradford Poulos at the Albert Einstein College of Medicine Tissue Bank for providing human fetal brain tissue. oligodendrocyte development. J. Neurosci. Res. 24, 548-557.

Barbin, G., Aigrot, M. S., Charles, P., Foucher,A., Grumet,M.Schachner, M., Zalc, B., and Lubetzki, C. (2004). Axonal cell-adhesion molecule L1 in CNS myelination. Neuron Glia Biol. $1,65-72$.

Barres, B. A., and Raff, M. C. (1993). Proliferation of oligodendrocyte precursor cells depends on electrical activity in axons. Nature 361, 258-260.

Bayatti, N., Sarma, S., Shaw, C., Eyre, J. A., Vouyiouklis, D. A., Lindsay, S., and Clowry, G. J. (2008). Progressive loss of PAX6, TBR2, NEUROD and TBR1 mRNA gradients correlates with translocation of EMX2 to the cortical plate during human cortical development. Eur. J. Neurosci. 28, 1449-1456.

Bayer, S. A., Altman, J., Russo, R. J., and Zhang, X. (1993). Timetables of neurogenesis in the human brain based on experimentally determined patterns in the rat. Neurotoxicology 14, 83-144.

Bergles, D. E., Roberts, J. D., Somogyi, P., and Jahr, C. E. (2000). Glutamatergic synapses on oligodendrocyte precursor cells in the hippocampus. Nature 405, 187-191.
Butt, A. M., Duncan, A., Hornby, M. F. Kirvell, S. L., Hunter, A., Levine, J. M. and Berry, M. (1999). Cells expressing the NG2 antigen contact nodes of Ranvier in adult CNS white matter. Glia 26, 84-91.

Butt, S. J., Fuccillo, M., Nery, S., Noctor, S., Kriegstein, A., Corbin, J. G., and Fishell, G. (2005). The temporal and spatial origins of cortical interneurons predict their physiological subtype. Neuron 48, 591-604

Campagnoni, A. T., and Macklin, W. B. (1988). Cellular and molecular aspects of myelin protein gene expression. Mol. Neurobiol. 2, 41-89.

Casper, K. B., and McCarthy, K. D. (2006) GFAP-positive progenitor cells produce neurons and oligodendrocytes throughout the CNS. Mol. Cell. Neurosci. 31, 676-684.

Chang, A., Tourtellote, W. W., Rudick, R. and Trapp,B.D. (2002).Premyelinating oligodendrocytes in chronic lesions of multiple sclerosis. N. Eng. J. Med. 346 , 165-173.

Charles, P., Reynolds, R., Seilhean, D., Rougon, G., Aigrot, M.S., Niezgoda, A., Zalc, B., and Lubetzki, C. (2002) Re-expression of PSA-NCAM by demyelinated axons: an inhibitor of remyelination in multiple sclerosis? Brain 125, 1972-1979.

Clancy, B., Finlay, B. L., Darlington, R. B., and Anand,K.J.S. (2007).Extrapolating brain development from experimental species to humans. Neurotoxicology 28 , 931-937.

Dawson, M. R., Polito, A., Levine, J. M. and Reynolds, R. (2003). NG2-expressing glial progenitor cells: an abundant and widespread population of cycling cells in the adult rat CNS. Mol. Cell. Neurosci. 24, 476-488.

Demerens, C., Stankoff, B., Logak, M., Anglade, P., Allinquant, B., Couraud, F., Zalc, B., and Lubetzki, C. (1996). Induction of myelination in the central nervous system by electrical activity. Proc. Natl. Acad. Sci. U.S.A. 93, 9887-9892.

Di Marco, R., Khademi, M., Wallstrom, E., Iacobaeus, E., Salvaggioo, A., Carcappa, S., Papoian, R., Nicoletti, F., and Olsson, T. (2001). Curative effects of recombinant human Inteleukin-6 in DA rats with protracted relapsing remitting experimental allergic encephalomyelitis. J. Neuroimmunol. 116, 168-177.

Diab, A., Zhu, J., Xiao, B. G., Mustafa, M. and Link, H. (1997). High IL-6 and low 
IL-10 in the central nervous system are associated with protracted relapsing EAE in DA rats. J. Neuropathol. Exp. Neurol. 56, 641-650.

Dubois-Dalcq, M., and Murray, K. (2000). Why are growth factors important in oligodendrocyte physiology? Pathol. Biol. (Paris) 48, 80-86.

Fertuzinhos, S., Krsnik, Z., Kawasawa, Y.I., Rasin, M. R., Kwan, K. Y., Chen, J. G., Judas, M., Hayashi, M., and Sestan, N. (2009). Selective depletion of molecularly defined cortical interneurons in human holoprosencephaly with severe striatal hypoplasia. Cereb. Cortex. doi: 10.1093/cercor/bhp009.

Fields, R. D. (2008). White matter in learning, cognition and psychiatric disorders. Trends Neurosci. 31, 361-370.

Filbin, M. T. (2003). Myelin-associated inhibitors of axonal regeneration in the adult mammalian CNS. Nat. Rev. Neurosci. 4, 703-713.

Filipovic, R., Jakovcevski, I., and Zecevic, N. (2003). GRO-alpha and CXCR2 in the human fetal brain and multiple sclerosis lesions. Dev. Neurosci. 25, 279-290.

Filipovic, R., Rakic, S., and Zecevic, N. (2002). Expression of Golli proteins in adult human brain and multiple sclerosis lesions. J. Neuroimmunol. 127, 1-12.

Filipovic, R., and Zecevic, N. (2005). Interaction between microglia and oligodendrocyte cell progenitors involves Golli proteins. Ann. N. Y. Acad. Sci. 1048, 166-174.

Filipovic, R., and Zecevic, N. (2008). The effect of CXCL1 on human fetal oligodendrocyte progenitor cells. Glia $56,1-15$.

Franklin, R. J. M. (2002). Why does remyelination fail in multiple sclerosis? Nat. Rev. Neurosci. 3, 705-714.

Gard, A. L., and Pfeiffer, S. E. (1993). Glial cell mitogens bFGF and PDGF differentially regulate development of $\mathrm{O}^{+}$ GalC-oligodendrocyte progenitors. Dev. Biol. 159, 618-630.

Georgieva, L., Moskvina, V., Peirce, T., Norton, N., Bray, N. J., Jones, L., Holmans, P., Macgregor, S.,Zammit, S., Wilkinson, J., Williams, H., Nikolov, I., Williams, N., Ivanov, D., Davis, K. L., Haroutunian, V., Buxbaum, J. D., Craddock, N., Kirov, G., Owen, M. J., and O'Donovan, M. C. (2006). Convergent evidence that oligodendrocyte lineage transcription factor 2 (OLIG2) and interacting genes influences susceptibility to schizophrenia. Proc. Natl. Acad. Sci. U.S.A. 103, 12469-12474.

Glabinski, A. R., O’Bryant, S., Selmaj, K., and Ransohoff, R. (2000). CXC chemokine receptors expression during relapsing experimental autoimmune encephalomyelitis. Ann. N. Y. Acad. Sci. 917, 135-144.

Götz, M., Stoykova, A., and Gruss, P. (1998). Pax6 controls radial glia differentiation in the cerebral cortex. Neuron 21, 1031-1044.

Grinspan, J. (2002). Cells and signaling in oligodendrocyte development. J. Neuropathol. Exp. Neurol. 61, 297-306.

Hack, M. A., Sugimori, M., Lundberg, C., Nakafuku, M., and Götz, M. (2004). Regionalization and fate specification in neurospheres: the role of Olig2 and Pax6. Mol. Cell. Neurosci. 25, 664-678.

Hardy, R., and Reynolds, R. (1991). Proliferation and differentiation potential of rat forebrain oligodendroglial progenitors both in vitro and in vivo. Development 111, 1061-1080.

He, W., Ingraham, C., Rising, L., Goderie, S., and Temple, S. (2001). Multipotent stem cells from the mouse basal forebrain contribute GABAergic neurons and oligodendrocytes to the cerebral cortex during embryogenesis. J. Neurosci. 21, 8854-8862.

Heins, N., Malatesta, P., Cecconi, F., Nakafuku, M., Tucker, K. L., Hack, M.A., Chapouton, P., Barde, Y. A., and Götz, M. (2002). Glial cells generate neurons: the role of the transcription factor Pax6. Nat. Neurosci. 5, 308-315.

Howard, B., Chen, Y., and Zecevic, N (2006). Cortical progenitor cells in the eveloping human telencephalon. Glia 53, 57-66.

Huang, J. K., Phillips, G. R., Roth, A. D., Pedraza, L., Shan, W., Belkaid, W., Mi, S., Fex-Svenningsen, A., Florens, L., Yates, J. R. III, and Colman, D. R. (2005). Glial membranes at the node of Ranvier prevent neurite outgrowth. Science 310, 1813-1817.

Irintchev,A., Rollenhagen,A., Troncoso, E., Kiss, J. Z., and Schachner, M. (2005). Structural and functional aberrations in the cerebral cortex of tenascin-C deficient mice. Cereb. Cortex 15, 950-962.

Ishibashi, T., Dakin, K. A., Stevens, B., Lee, P. R., Kozlov, S. V., Stewart, C. L., and Fields, R. D. (2006). Astrocytes promote myelination in response to electrical impulses. Neuron 49, 823-832.

Jakovcevski, I., Mo, Z., and Zecevic, N. (2007). Down-regulation of the axonal polysialic acid-neural cell adhesion molecule expression coincides with the onset of myelination in the human fetal forebrain. Neuroscience 149, 328-337.

Jakovcevski, I., Siering, J., Hargus, G., Karl, N., Hoelters, L., Djogo, N., Yin, S., Zecevic, N., Schachner, M., and
Irintchev,A. (2009). Close homologue of adhesion molecule L1 promotes survival of Purkinje and granule cells and granule cell migration during murine cerebellar development. $J$. Comp. Neurol. 513, 496-510.

Jakovcevski, I., and Zecevic, N. (2005a). Sequence of oligodendrocyte development in the human fetal telencephalon. Glia 49, 480-491.

Jakovcevski, I., and Zecevic, N. (2005b). Olig transcription factors are expressed in oligodendrocyte and neuronal cells in human fetal CNS. J. Neurosci. 25, 10064-10073.

Kessaris, N., Fogarty, M., Iannarelli, P., Grist, M., Wegner, M., and Richardson, W.D. (2006). Competing waves of oligodendrocytes in the forebrain and postnatal elimination of an embryonic lineage. Nat. Neurosci. 9, 173-179.

Kinney, H. C., Karthigasan, J., Borenshteyn, N. I., Flax, J. D., and Kirschner, D. A. (1994). Myelination in the developing human brain: biochemical correlates. Neurochem. Res 19, 983-996.

Kostovic, I., and Judas, M. (2002). Correlation between the sequential ingrowth of afferents and transient patterns of cortical lamination in preterm infants. Anat. Rec. 267, 1-6.

Kostovic, I., and Rakic, P. (1990). Developmental history of the transient subplate zone in the visual and somatosensory cortex of the macaque monkey and human brain. J. Comp. Neurol. 297, 441-470.

Lachapelle, F., Avellana-Adalid, V., NaitOumesmar, B., and Baron-Van Evercooren, A. (2002). Fibroblast growth factor-2 (FGF-2) and plateletderived growth factor $\mathrm{AB}$ (PDGF $\mathrm{AB}$ ) promote adult SVZ-derived oligodendrogenesis in vivo. Moll. Cell. Neurosci. 20, 390-403.

Levine, J. M., Reynolds, R., and Fawcett, J. W.(2001). Theoligodendrocyte precursor cell in health and disease. Trends Neurosci. 24, 39-47.

Lin, S. C., Huck, J. H., Roberts, J. D., Macklin, W. B., Somogyi, P., and Bergles, D. E. (2005). Climbing fiber innervation of NG2-expressing glia in the mammalian cerebellum. Neuron 46, 773-785.

Lu, Q. R., Sun, T., Zhu, Z., Ma, N. Garcia, M., Stiles, C. D., and Rowitch, D. H. (2002). Common developmental requirement for olig function indicates a motor neuron/ oligodendrocyte connection. Cell 109, 75-86.

Lu, Q. R., Yuk, D.-I., Alberta, J. A., Zhu, Z. Pawlitzky, I., Chan, J., McMahon, A. P., Stiles, C. D., and Rowitch, D. H. (2000). Sonic hedgehog-regulated oligodendrocyte lineage genes encoding bHLH proteins in the mammalian central nervous system. Neuron 25, 317-329.

Luskin, M. B. (1993). Restricted proliferation and migration of postnatally generated neurons derived from the forebrain subventricular zone. Neuron 11, 173-189.

Macklin, W. B., Weill, C. L., and Deininger, P. L. (1986). Expression of myelin proteolipid and basic protein mRNAs in cultured cells. J. Neurosci. Res 16, 203-217.

Malatesta, P., Hack, M. A., Hartfuss, E., Kettenmann, H., Klinkert, W., Kirchhoff, F., and Gotz, M. (2003). Neuronal or glial progeny: regional differences in radial glia fate. Neuron 37, 751-764.

Marin, O., and Rubenstein J. L. (2001). A long, remarkable journey: tangential migration in the telencephalon. Nat. Rev. Neurosci. 2, 780-790.

Marshall, C. A., and Goldman, J. E. (2002). Subpallial Dlx2-expressing cells give rise to astrocytes and oligodendrocytes in the cerebral cortex and white matter. J. Neurosci. 22, 9821-9830.

Mason, J. L., Xuan, S., Dragatsis, I. Efstratiadis, A., and Goldman, J. E. (2003). Insulin-like growth factor (IGF) signaling through type 1 IGF receptor plays an important role in remyelination. J. Neurosci. 23, 7710-7718.

McKellar, C. E., and Shatz, C. J. (2008). Synaptogenesis in purified cortical subplate neurons. Cereb. Cortex [Epub ahead of print].

Mehanna, A., Mishra, B., Kurschat, N., Schulze, C., Bian, S., Loers, G. Irintchev, A., and Schachner, M. (2009). Polysialic acid glycomimetics promote myelination and functional recovery after peripheral nerve injury in mice. Brain 132, 1449-1462.

Mi, S., Hu, B., Hahm, K., Luo, Y., Kam Hui, E. S., Yuan, Q., Wong, W. M., Wang, L., Su, H., Chu, T. H., Guo, J., Zhang, W., So, K. F., Pepinsky, B., Shao, Z., Graff, C., Garber, E., Jung, V., Wu, E. X., and Wu, W. (2007). LINGO-1 antagonist promotes spinal cord remyelination and axonal integrity in MOG-induced experimental autoimmune encephalomyelitis. Nat. Med. 13, 1228-1233.

Mi, S., Miller, R. H., Lee, X., Scott, M. L., Shulag-Morskaya, S., Shao, Z., Chang, J., Thill, G., Levesque, M., Zhang, M., Hession, C., Sah, D., Trapp, B., He, Z., Jung, V., McCoy, J.M., and Pepinsky, R. B. (2005). LINGO-1 negatively regulates myelination by oligodendrocytes. Nat. Neurosci. 8, 745-751. 
Miller, R. H. (1996). Oligodendrocyte origins. Trends Neurosci. 19, 92-96.

Miyata, T., Kawaguchi, A., Okano, H., and Ogawa, M. (2001). Asymmetric inheritance of radial glial fibers by cortical neurons. Neuron 31, 727-741

Miyata, T., Kawagushi, A., Saito, K., Kawano, M., Muto, T., and Ogawa, M. (2004). Asymmetric production of surface-dividing and non-surface dividing cortical progenitor cells. Development 130, 3133-3145.

Miyoshi, G., Butt, S. J., Takebayashi, H., and Fishell, G. (2007). Physiologically distinct temporal cohorts of cortical interneurons arise from telencephalic Olig2-expressing precursors. J. Neurosci. 27, 7786-7798.

Mo, Z., Moore, A. R., Filipovic, R., Ogawa, Y., Kazuhiro, I., Antic, S. D., and Zecevic, N. (2007). Human cortical neurons originate from radial glia and neuron-restricted progenitors. $J$. Neurosci. 27, 4132-4145.

Mo, Z., and Zecevic, N. (2008). Is pax6 critical for neurogenesis in the human fetal brain? Cereb. Cortex 18, 1455-1465.

Mo, Z., and Zecevic, N. (2009). Human fetal radial glia cells generate oligodendrocytes in vitro. Glia 57 , 490-498.

Moore, A. R., Filipovic, R., Mo, Z., Rasband, M. N., Zecevic, N., and Antic, S. D. (2008). Electrical excitability of early neurons in the human cerebral cortex during the second trimester of gestation. Cereb. Cortex [Epub ahead of print].

Nait-Oumesmar, B., Picard-Riera, N., Kerninon, C., Decker, L., Seilhean, D., Hoglinger, G.U.,Hirsch, E.C., Reynolds, R., and Baron-Van Evercooren, A. (2007). Activation of subventricular zone in multiple sclerosis: evidence for early glial progenitors. Proc. Natl. Acad. Sci. U.S.A. 104, 4694-4699.

Nery, S., Wichterle, H., and Fishell, G. (2001). Sonic hedgehog contributes to oligodendrocyte specification in mammalian forebrain. Development 128, 527-540.

Nishiyama, A., Komitova, M., Suzuki, R., and Zhu, X. (2009). Polydendrocytes (NG2 cells): multifunctional cells with lineage plasticity. Nat. Rev. Neurosci. 10, 9-22.

Noctor, S. C., Flint, A. C., Weissman, T. A., Dammerman, R. S., and Kriegstein, A. R. (2001). Neurons derived from radial glial cells establish radial units in neocortex. Nature 409, 714-720.

Olivier, G., and Pineau, H. (1962). Horizons de Streeter et age embrionnaire. Bull. Ass. Anat. 47e, 573-576.

Omari, K. M., John, G., Lango, R., and Raine, C. S. (2006). Role of CXCR2 and CXCL1 on glia in multiple sclerosis. Glia 53, 24-31.

Omari, K. M., John, G. R., Sealfon, S. C. and Raine, C.S. (2005). CXC chemokine receptors on human oligodendrocytes: implications for multiple sclerosis. Brain 128, 1003-1015.

Ongur, D., Drevets, W. C., and Price, J. L. (1998). Glial reduction in the subgenual prefrontal cortex in mood disorders. Proc. Natl. Acad. Sci. U.S.A. 95, 13290-13295.

O’Rahilly, R. (1979). Early human development and the chief sources of information on staged human embryos. Eur. J. Obstet. Gynecol. Reprod. Biol. 9, 273-280.

O'Rahilly, R., Muller, F., Hutchins, G. M., and Moore, G. W. (1987). Computer ranking of the sequence of appearance of 73 features of the brain and related structures in staged human embryos during the sixth week of development. Am. J. Anat. 180, 69-86.

Orentas, D. M., and Miller, R. H. (1996). The origin of spinal cord oligodendrocytes is dependent on local influences from the notochord. Dev. Biol. 177, 43-53.

Papastefanaki, F., Chen, J., Lavdas, A. A. Thomaidou, D., Schachner, M., and Matsas, R. (2007). Grafts of Schwann cells engineered to express PSANCAM promote functional recovery after spinal cord injury. Brain 130, 2159-2174.

Petanjek, Z., Judas, M., Kostović, I., and Uylings, H. B. (2008). Lifespan alterations of basal dendritic trees of pyramidal neurons in the human prefrontal cortex: a layer-specific pattern. Cereb. Cortex 18, 915-929.

Pfeiffer, S. E., Warrington, A. E., and Bansal, R. (1993). The oligodendrocyte and its many cellular processes. Trends Cell Biol. 3, 191-197.

Pringle, N.P., Mudhar,H.S., Collarini, E. J., and Richardson, W. D. (1992). PDGF receptors in the rat CNS: during late neurogenesis, PDGF alpha-receptor expression appears to be restricted to glial cells of the oligodendrocyte lineage. Development 115, 535-551.

Pringle, N. P., and Richardson, W. D. (1993). A singularity of PDGF alphareceptor expression in the dorsoventral axis of the neural tube may define the origin of the oligodendrocyte lineage. Development 117, 525-533.

Pringle, N. P., Yu, W. P., Guthrie, S. Roelink, H., Lumsden, A., Peterson, A. C., and Richardson, W. D. (1996). Determination of neuroepithelial cell fate: induction of the oligodendrocyte lineage by ventral midline cells and sonic hedgehog. Dev. Biol. 177, 30-42.
Raff, M. C. (1989). Glial cell diversification in the rat optic nerve. Science 243 1450-1455.

Raine, C. S., Scheinberg, L., and Waltz, J. M. (1981). Multiple sclerosis. Oligodendrocyte survival and proliferation in an active established lesions. Lab. Invest. 45, 534-546.

Rakic, S., and Zecevic, N. (2000) Programmed cell death in the developing human telencephalon. Eur. J. Neurosci. 12, 2721-2734.

Rakic, S., and Zecevic, N. (2003a). Early oligodendrocyte progenitor cells in the human fetal telencephalon. Glia 41, 117-127.

Rakic, S., and Zecevic, N. (2003b). Emerging complexity of layer I in human cerebral cortex. Cereb. Cortex 13, 1072-1083.

Ransohoff, R. M., Howe, C. L., and Rodriguez, M. (2002). Growth factor treatment of demyelinating disease: at last, a leap into the light. Trend Neurosci. 22, 512-515.

Reynolds, R., and Hardy, R. (1997). Oligodendroglial progenitors labeled with the $\mathrm{O} 4$ antibody persist in the adult rat cerebral cortex in vivo. $J$. Neurosci. Res. 47, 455-470.

Richardson, W. D., Smith, H. K., Sun, T. Pringle, N.P.,Hall,A., and Woodruff, R. (2000). Oligodendrocyte lineage and the motor neuron connection. Glia 29, 136-142.

Rio Hortega, D. P. (1921). Histogenesis y evolucion normal; exodo y distribucion regional de la microglia. Memor. Real. Soc. Esp. Hist. Nat. 11, 213-268.

Rivers, L. E., Young, K. M., Rizzi, M., Jamen, F., Psachoulia, K., Wade, A. Kessaris, N., and Richardson, W. D. (2008). PDGFRA/NG2 glia generate myelinating oligodendrocytes and piriform projection neurons in adult mice. Nat. Neurosci. 11, 1392-1401.

Rivkin, M. J., Flax, J., Mozell, R. Osathanondh, R., Volpe, J. J., and VillaKomaroff, L. (1995). Oligodendroglial development in human fetal cerebrum. Ann. Neurol. 38, 92-101.

Robertson, J. D. (1899). On a new method of obtaining a black reaction in certain tissue elements of the central nervous system (platinum method). Scott. Med. Surg. J. 4, 23-30.

Robinson, S., and Franic, L. A. (2001). Chemokine GRO1 and the spatial and temporal regulation of oligodendrocyte precursor proliferation. Dev. Neurosci. 23, 338-345.

Robinson, S., Tani, M., Strieter, R. M. Ransohoff, R. M., and Miller, R. H (1998). The chemokine growth-regulated oncogene-alpha promotes spinal cord oligodendrocyte precursor proliferation. J. Neurosci. 18, 10457-10463.
Rowitch, D. H. (2004). Glial specification in the vertebrate neural tube. Nat. Rev. Neurosci. 5, 409-419.

Sakurai, Y., Nishimura, D., Yoshimura, K., Tsuruo, Y., Seiwa, C., and Asou, H. (1998).Differentiation of oligodendrocyte occurs in contact with astrocyte. $J$. Neurosci. Res. 52, 17-26.

Sanai, N., Tramontin, A. D., QuinonesHinojosa, A., Barbaro, N. M., Gupta, N., Kunwar, S., Lawton, M. T., McDermott, M. W., Parsa, A. T., Manuel-Garcia Vertugo, J., Berger, M. S., and Alvarez-Buylla, A. (2004). Unique astrocyte ribbon in adult human brain contains neural stem cells but lacks chain migration. Nature 427, 740-744.

Scolding, N., Franklin, R., Stevens, S., Heldin, C. H., Compston, A., and Newcombe,J.(1998). Oligodendrocyte progenitors are present in the normal adult human CNS and in the lesions of multiple sclerosis. Brain 121, 2221-2228

Scolding, N. J., Rayner, P. J., Sussman, J., Shaw, C., and Compston, D. A. (1995). A proliferative adult human oligodendrocyte progenitor. Neuroreport $6,441-445$

Sheppard, A. M., Hamilton, S. K., and Pearlman, A. L. (1991). Changes in the distribution of extracellular matrix components accompany early morphogenetic events of mammalian cortical development. J. Neurosci. 11, 3928-3942.

Sommer, I., and Schachner, M. (1981). Monoclonal antibodies (O1 to $\mathrm{O} 4)$ to oligodendrocyte cell surfaces: an immunocytological study in the central nervous system. Dev. Biol. 83 311-327.

Spassky, N., Olivier, C., Perez-Villegas, E., Goujet-Zalc, C., Martinez, S., Thomas, J., and Zalc, B. (2000). Single or multiple oligodendroglial lineages: a controversy. Glia 29, 143-148.

Stallcup, W. B., and Beasley, L. (1987). Bipotential glial precursor cells of the optic nerve express NG2 proteoglycan. J. Neurosci. 7, 2737-2744.

Stark, A. K., Uylings, H. B., Sanz-Arigita, E., and Pakkenberg, B. (2004). Glial cell loss in the anterior cingulate cortex, a subregion of the prefrontal cortex, in subjects with schizophrenia. Am. J. Psychiatry 161, 882-888.

Stevens, B., Tanner, S., and Fields, R. D. (1998). Control of myelination by specific patterns of neural impulses. J. Neurosci. 18, 9303-9311.

Stillman, A. A., Krsnik, Z., Sun, J., Rasin, M. R., State, M. W., Sestan, N., and Louvi,A. (2009). Developmentally regulated and evolutionarily conserved expression of SLITRK1 in brain circuits implicated in Tourette syndrome. J. Comp. Neurol. 513, 21-37. 
Takebayashi, H., Nabeshima, Y., Yoshida, S., Chisaka, O., Ikenaka, K., and Nabeshima, Y.-C. (2002). The basic helix-loop-helix factor olig2 is essential for the development of motoneuron and oligodendrocyte lineages. Curr. Biol. 12, 1157-1163.

Takebayashi, H., Yoshida, S., Sugimori, M., Kosako, H., Kominami, R., Nakafuku, M., and Nabeshima, Y. (2000). Dynamic expression of basic helix-loop-helix olig family members: Implication of olig2 in neuron and oligodendrocyte differentiation and identification of a new member, olig3. Mech. Dev. 99, 143-148.

Teicher, M. H., Dumont, N. L., Ito, Y., Vaituzis, C., Giedd,J.N., and Andersen, S. L. (2004). Childhood neglect is associated with reduced corpus callosum area. Biol. Psychiatry 56, 80-85.

Tekki-Kessaris, N., Woodruff, R., Hall, A. C., Gaffield, W., Kimura, S., Stiles, C. D., Rowitch, D. H., and Richardson, W. D. (2001). Hedgehogdependant oligodendrocyte lineage specification in the telencephalon. Development 128, 2545-2554.

Temple, S., and Raff, M. C. (1986). Clonal analysis of oligodendrocyte development in culture: evidence for a developmental clock that counts cell divisions. Cell 44, 773-779.

Timsit, S., Martinez, S., Allinquant, B., Peyron, F., Puelles, L., and Zalc, B. (1995). Oligodendrocytes originate from restricted zone of embryonic ventral neural tube defined by DM20 mRNA. J. Neurosci. 15, 1012-1024.

Tkachev, D., Mimmack, M. L., Ryan, M. M., Wayland, M., Freeman, T., Jones, P. B., Starkey, M.,
Webster, M. J., Yolken, R. H., and Bahn, S. (2003). Oligodendrocyte dysfunction in schizophrenia and bipolar disorder. Lancet 362, 798-805.

Tosic, M., Rakic, S., Matthieu, J. M., and Zecevic, N. (2002). Identification of Golli and myelin basic proteins in human brain during early development. Glia 37, 219-228.

Trapp, B. D., and Nave, K. A. (2008). Multiple sclerosis: an immune or neurodegenerative disorder? Annu. Rev. Neurosci. 31, 247-269.

Ulfig, N., Nickel, J., and Saretzki, U. (1998). Alterations in myelin formation in fetal brains of twins. Pediatr. Neurol. 19, 287-293.

Vallstedt, A., Klos, J. M., and Ericson, J. (2005). Multiple dorsoventral origins of oligodendrocyte generation in the spinal cord and hindbrain. Neuron 45, 55-67.

Verity, A. N., and Campagnoni, A. T. (1988). Regional expression of myelin protein genes in the developing mouse brain: in situ hybridization studies. J. Neurosci. Res. 21, 238-248.

Verley, R. (1977). Comparative development of the mammalian nervous system. Rev. Electroencephalogr. Neurophysiol. Clin. 7, 245-254.

Warrington, A. E., and Pfeiffer, S. E. (1992). Proliferation and differentiation of $\mathrm{O}^{+}$oligodendrocytes in the postnatal rat cerebellum: analysis in unfixed tissue slices using anti-glycolipid antibodies. J. Neurosci. Res. 33, 338-353.

Willenborg, D. O., Fordham, S. A., Cowden, W. B., and Ramshaw, I. A. (1995). Cytokines and murine autoimmune encephalomyelitis: inhibition or enhancement of disease with antibodies to select cytokines, or by delivery of exogenous cytokines using a recombinant vaccinia virus system. Scand. J. Immunol. 41, 31-41.

Wilson, H. C., Onischke, C., and Raine, C.S. (2003). Human oligodendrocyte precursor cells in vitro: phenotypic analysis and differential response to growth factors. Glia 44, 153-165.

Wolswijk, G. (1998).Chronic stage multiple sclerosis contain a relatively quiescent population of oligodendrocyte precursor cells. J. Neurosci. 18, 601-609.

Yakovlev, P. I., and Lecourse, A. R. (1967) The myelinogenetic cycles in regional maturation of the brain. In Regional Development of the Brain in Early Life, A. Minkowsky, ed (Oxford, Blackwell), pp. 3-70.

Yeh, H. J., Silos-Santiago, I., Wang, Y. X. George, R. J., Snider, W. D., and Deuel, T. F. (1993). Developmental expression of the platelet-derived growth factor alpha-receptor gene in mammalian central nervous system. Proc. Natl. Acad. Sci. U.S.A. 90, 1952-1956.

Zecevic, N. (2004). Specific characteristics of radial glia in the human fetal telencephalon. Glia 48, 27-35.

Zecevic, N., Andjelkovic, A. Matthieu, J. M., and Tosic, M. (1998). Myelin basic protein is expressed in the human embryonic CNS. Dev. Brain Res. 105, 97-108.

Zecevic, N., Chen, Y., and Filipovic, R. (2005). Contributions of the cortical subventricular zone to the development of the human cerebral cortex. $J$. Comp. Neurol. 491, 109-122.
Zhang, S.-C., Ge, B., and Duncan, I. D. (2000). Tracing human oligodendroglial development in vitro. J. Neurosci. Res. 59, 421-429.

Zhou, Q., and Anderson, D. J. (2002). The bHLH transcription factors olig2 and olig1 couple neuronal and glial subtype specification. Cell 109, 61-73.

Zhou, Q., Choi, G., and Anderson, D. J. (2001). The bHLH transcription factor Olig2 promotes oligodendrocyte differentiation in collaboration with Nkx2.2. Neuron 31, 791-807.

Zhou, Q., Wang, S., and Anderson, D. J. (2000). Identification of a novel family of oligodendrocyte lineage-specific basic helix-loop-helix transcription factors. Neuron 25, 331-343.

Conflict of Interest Statement: Authors declare that the research was conducted in the absence of any commercial or financial relationships that would be construed as a potential conflict of interest.

Received: 01 May 2009; paper pending published: 14 May 2009; accepted: 19 May 2009; published online: 01 June 2009. Citation: Jakovcevski I, Filipovic R, Mo Z, Rakic S and Zecevic N (2009) Oligodendrocyte development and the onset of myelination in the human fetal brain. Front. Neuroanat. (2009) 3:5. doi:10.3389/neuro.05.005.2009 Copyright (c) 2009 Jakovcevski, Filipovic, Mo, Rakic and Zecevic. This is an openaccess article subject to an exclusive license agreement between the authors and the Frontiers Research Foundation, which permits unrestricted use, distribution, and reproduction in any medium, provided the original authors and source are credited. 